Florida International University

FIU Digital Commons

$4-4-2000$

\title{
The effects of cross-age peer tutoring on writing and reading comprehension skills and attitudes and self- perceptions as writers of third and fourth grade students
}

Artis McChesney Gray

Florida International University

Follow this and additional works at: https://digitalcommons.fiu.edu/etd

\section{Recommended Citation}

Gray, Artis McChesney, "The effects of cross-age peer tutoring on writing and reading comprehension skills and attitudes and self- perceptions as writers of third and fourth grade students" (2000). FIU Electronic Theses and Dissertations. 3947.

https://digitalcommons.fiu.edu/etd/3947

This work is brought to you for free and open access by the University Graduate School at FIU Digital Commons. It has been accepted for inclusion in FIU Electronic Theses and Dissertations by an authorized administrator of FIU Digital Commons. For more information, please contact dcc@fiu.edu. 
FLORIDA INTERNATIONAL UNIVERSITY

Miami, Elorida

THE EEFECTS OF CROSS-AGE PEER TUTORING ON WRITING AND

READING COMPREHENSION SKILLS AND ATTITUDES AND SELE-

PERCEPTIONS AS WRITERS OE THIRD AND FOURTH GRADE STUDENTS

A dissertation submitted in partial fulfillment of the requirements for the degree of

\author{
DOCTOR OF EDUCATION \\ in \\ CURRICULUM AND INSTRUCTION
}

by

Artis Mcchesney Gray 
To: Dean Linda Blanton

College of Education

This dissertation, written by Artis McChesney Gray, and entitled The Effects of Cross-Age Peer Tutoring On Writing and Reading Comprehension Skills and Attitudes and SelfPerceptions as Writers of Third and Fourth Grade Students, having been approved in respect to style and intellectual content is referred to you for judgement.

We have read this dissertation and recommend that it be approved.

Lynne Miller

Ina Parks Howell

Sharon Kossack, Major Professor

Date of Defense: April 4, 2000

The dissertation of Artis McChesney Gray is approved.

Dean Linda Blanton College of Education

Dean Richard L. Campbell Division of Graduate Studies

Elorida International University, 2000 
(c) Copyright 2000 by Artis Gray

A11 rights reserved. 
DEDICATION

I dedicate this dissertation to my husband, Patrick Gray, my children, David and Victoria Gray, and Lori and Karl Sessler, my grand children, Marlee Gray and the two blessings on the way, and my parents, Robert and Mary Weems. Without their patience, support, understanding, and most of all love, the completion of this work would not have been possible. 


\section{ACKNOWLEDGMENTS}

I wish to express my gratitude to Drs. Sharon Kossack, Lynne Miller, and Ina Parks Howell for their guidance, patience, and encouragement. Without the strength and support of this wonderful doctoral committee, who gave so unselfishly of their time and wisdom, I could not have been successful. A special thank you to Dr. Kossack and Dr. Miller, who by the experience of being in their classes, taught what a real teacher "looks like and sounds like." Dr. Howell deserves a special thank you for agreeing to be on my committee after the death of Dr. Gay. I will never forget the hours of patience guidance she gave while working with me.

I want to remember Dr. Gay, who planted the seed to begin this quest, and Dr. Matthewson who encouraged me to reach beyond what I thought I could do. I will always hold my memories of them dear and I wish they had been with me to complete this project.

Thank you to the principal, Mr. Eredric Zerlin, and the teachers who helped me during the study sheila Washington, Ursula Elecha-Lewis and Susan Singer. Also, thank you to the children who were involved in the study. 
I will always remember their enthusiasm and hard work they put into the tutoring sessions.

I want to express my gratefulness to my family. My husband, Dr. Patrick Gray, who has been my gentle and patient push through it all, and my children, David and Victoria Gray, and Lori and Karl Sessler, for their love, support, patience, and understanding during this long project. And to my parents, Robert and Mary Weems, who did not live to see me finish, but encouraged me to begin and to continue.

Again, thank you to Dr. Kossack, my mentor, who by her own example taught me that there is no such thing as giving up.

Thank you all. I could never have done it without you! 
ABSTRACT OE THE DISSERTATION

THE EEEECTS OF CROSS-AGE PEER TUTORING ON WRITING AND READING COMPREHENSION SKILLS AND ATTITUDES AND SELEPERCEPTIONS AS WRITERS OF THIRD AND FOURTH GRADE STUDENTS by

\section{Artis McChesney Gray}

Florida International University, 2000

$$
\text { Miami, Florida }
$$

Professor Sharon W. Kossack, Major Professor

The purpose of this study was to investigate the effects of cross-age peer writing response groups on the writing and reading achievement of third and fourth grade students. Students' attitudes about writing and their perceptions of themselves as writers were also measured at the end of the study.

One hundred and twenty-two third and fourth grade students enrolled in a public school in a middle-class, mulit-cultural neighborhood participated in the study. Four existing classes of students were randomiy assigned to either the experimental condition (EC) or the control condition (CC). Both groups were pretested and posttested 
for writing and reading achievement. The intervention, cross-age peer writing groups, met for eleven weeks. Three hypotheses were examined in this study: (a) writing improvement score, (b) reading comprehension improvement score, and (c) students' attitudes toward writing and their perception of themselves as writers based on the five scales measured on the Writer self-Perception Scale.

ANOVAs were done on the pretests and posttests for writing and the Stanford Achievement Test reading comprehension subtest scores for the year of the study and the previous year. ANOVAs were also done for the five areas of the Writer Self-Perception Scale. Crosstabulations were also used to compare improvement level verses treatment group, and grade level. Analysis of the data revealed that there was no evidence that the tutoring (EC) groups made more progress than the non-tutoring (CC) groups in writing and reading. There was evidence of growth in writing, especially by the fourth graders. Most importantly, the fourth grade tutors, the experimental group, had the most positive feelings about writing and themselves as writers. 
I. INTRODUCTION. . . . . . . . . . . . . . . . . . I

II. REVIEW OE THE LITERATURE.................16

A History of Language Arts K-12. . . . . . . . . 16 Research in Writing. . . . . . . . . . . . .26 Writing Instruction. . . . . . . . . . . . . 28 Cross-Age Peer Response Groups. . . . . . . . . 34

III. METHODOLOGY. . . . . . . . . . . . . . . . . .41 Description of the Research Context....... . 41 Overview of the Study. . . . . . . . . . . . . .44 Research Design. . . . . . . . . . . . . .46 Hypotheses. . . . . . . . . . . . . . . 47 Procedures and Methods . . . . . . . . . . .49 Experimental Procedures. . . . . . . . . . .60

IV. RESULTS. . . . . . . . . . . . . . . . .69

Effects of Variables . . . . . . . . . . . .69

Analysis. . . . . . . . . . . . . . 70

Results. . . . . . . . . . . . . 70

Summary. . . . . . . . . . . . . . .86

V. DISCUSSION. . . . . . . . . . . . . . . . . . 91

Summary of the Findings. . . . . . . . . . . 91 Discussion. . . . . . . . . . . . . . . . . 94

Reflections of a Teacher-Researcher. . . . . . .99

Recommendations for Future Research. . . . . . 102

Final Thoughts. . . . . . . . . . . . 104

LIST OF REEERENCES. . . . . . . . . . . . . 106

APPENDICES. . . . . . . . . . . . . . . 117

VITA. . . . . . . . . . . . . . . 149 


\section{LIST OF TABLES}

TABLE

PAGE

1. Student Ethnic Population 1997/1998. . . . . . . . 42

2. Ethnic Population of the Four Treatment Groups. . . 43

3. Timeline of the Study and Data Collection. . . . . .506

4. Writing Scores. . . . . . . . . . . . . 73

5. Differences on the Stanford Achievement Test in Reading Comprehension Scores . . . . . . . . . 74

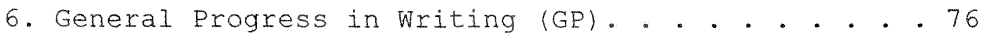

7. Specific Progress in Writing (SP). . . . . . . . . 77

8. Observational Progress in Writing (OC). . . . . . 78

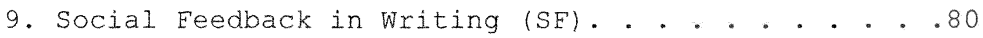

10. Psychological States While Writing (PS). . . . . .81

11. Fisher's Exact Test for Improvement Level and Treatment Groups. . . . . . . . . . . . . 85

12. Proportions Improving "more than expected". . . . . 85 
CHAPTER ONE

\section{INTRODUCTION}

Because of the reciprocal nature of reading and writing, improvement in writing skills may improve reading skills. Writing instruction is coming to the fore in elementary education because it is recognized as essential for communication and learning. Good writing skills can be taught through quality instruction. Because of the social nature of the writing process, it is reasonable to consider that learning may be facilitated by students working with other students for the mutual improvement of their writing. This research examines cross-age peer tutoring as a potential method of improving the skills associated with process writing, and reading, as well as the attitudes toward writing and the self-perceptions as writers of the students involved in the study.

The purpose of this chapter is to present the (a) background of the problem, (b) purpose of the study, (c) statement of the problem, (d) assumptions, (e) limitations, and ( $f$ ) definitions of terms for this study.

\section{Background of the Problem}

The effectiveness of our schools is often the focal point of much concern and criticism in our nation. A 
report by the National Commission on Excellence in

Education titled A Nation at Risk (1983) stated that 23 million American adults were functionally illiterate as assessed by the simplest tests of everyday reading and writing. The National Assessment of Educational Progress Writing Evaluation (1984) found that students in fourth, eighth, and eleventh grades could not write adequately, except in response to the simplest tasks, and wrote at the same low level of competence as students in 1974 (Austin, 1987). The 1990 National Assessment of Education found that the average performance of fourth and eleventh grade students in writing was unchanged from 1984 when they first administered the test. The average writing performance for eighth graders declined from the 1984 figures.

The 1996 report indicated an overall pattern of decline in performance across the assessment years for eleventh grade students. The average writing scores of eighth graders fluctuated, with the low point being 1990 and a rebound in 1992. Overall, there were no consistent patterns of increases or decreases for either eighth grade or fourth grade. The 1996 scores did not differ significantly from their 1984 counterparts. 
The Presidential Commission recommended in Becoming a Nation of Readers (1985) that educators integrate the instruction of reading and writing into a strategic approach, emphasizing process over product in the school curriculum instead of separate instruction, as has been the case in the majority of classrooms.

Research on elementary writing/language arts instruction has indicated that the time allotted to these subjects focused primarily on isolated language mechanics skills, with little time allocated to actual writing (Bridge \& Hiebert, 1985; Graves, 1984). Two parallel trends have created the potential for change in elementary writing and language arts instruction (Stevens, Madden, Slavin, \& Farnish, 1987). First, basic research developed a clearer understanding of the cognitive processes involved in writing (Bereiter \& Scardamalia, 1982; Flower \& Hayes, 1980; McCutchen \& Perfetti, 1983; Scardamalia \& Bereiter, 1986). Secondly, the increased use of writing process models, in which students are taught a cycle of planning, drafting, revising, editing, and publishing compositions, has placed emphasis on writing instruction (Calkins 1983; Graves, 1983a; Gray \& Myers, 1978). 
The Department of Education, through the National Center for Educational Statistics, prepared a 1990 portfolio study of students' school-based writing, which revealed the types of writing used by students in grades four and eight (Gentile, 1992). The majority of the writing in these two grades was either informative or narrative in style. Informative writing comprised 51\% of the total writing in grade four and $59 \%$ of the writing in grade eight. In grade four, $36 \%$ of the writing was narrative and in grade eight, $30 \%$ of the writing was narrative. The 1990 study looked for evidence of process writing strategies in the students' writing. The study concluded that only $38 \%$ of the fourth grade students and only $43 \%$ of the eighth grade students used process writing strategies in their writing.

Concern about the level of literacy in this country prompted an increased interest and emphasis on reading and writing skills in the curriculum (Eranklin, 1992). Donald Graves conducted a study for the Ford Foundation on the status of writing (Graves, 1978). He interviewed people from all walks of life about their learning and writing experiences while in school. Sixty-five percent of those interviewed could not cite a single teacher who had helped 
them with their writing. Thirty percent could name one teacher who had helped them with their writing; no one had more than two teachers who had helped them with writing. The study also revealed that the teachers identified as good teachers of writing by the people interviewed were also the teachers they remembered as the good teachers in their school experience. Of the thirty-eight professional writers interviewed in the study, not one of them reported learning to write in school.

A study by Iichteig, Johnson, and Johnson (1994) exploring undergraduate elementary education majors" reflections on learning to read and write, their perceptions about the language arts, and their expectations for language arts teaching experiences, also indicates a need for improved instruction in writing. Of the undergraduates who responded, the vast majority perceived themselves as having adequate reading and writing skilis. They ranked writing as both the least pleasurable and most difficult language arts skill to learn. A majority also stated that they believed that writing would be the most difficult skill to teach (72\%). Most of the students (66\%) looked forward to teaching reading; 50\% looked forward least to teaching writing. The majority of these future 
teachers said they were not good writers, didn't like to write, and lacked confidence in themselves as writers.

The tabulated responses (Lickteig, et al. 1994)

indicated that the majority of the respondents named family members more frequently than teachers as being influential in their reading development (by almost 2 to 1 ). In contrast, teachers had the greatest influence on the students as writers. Emig (1971), as a result of her research with $12^{\text {th }}$ graders, noted that school seemed to have a significant, and sometimes negative, influence on students' ability to behave and think like writers.

Since teachers tend to emphasize in their classrooms what they enjoy and feel comfortable with, ways need to be found to teach writing that will improve writing skills, as well as the attitudes of both teachers and students toward writing. This study will address this problem at the elementary school level.

\section{Purpose of the Study}

This research has three major purposes. First, it will examine the impact of cross-age peer tutoring on the writing skills of third and fourth grade students who are all receiving direct instruction in writing as a process. Second, it will determine if the tutoring sessions will 
have any effect on the reading skills of the tutors and tutees. Third, this research examines students' attitudes toward writing and the students' perceptions of themselves as writers at the end of the study. Further elaboration of each purpose will follow.

Research has shown strong evidence that peer tutoring has many positive effects on math, reading, spelling, vocabulary acquisition, and other content areas (Allen, 1976; Rekrut, 1994), but offers little evidence of the use of peer tutoring for teaching process writing, especially at the elementary school level. In their Note From the Series Editors (Dahl \& Earnan, 1998), James Elood and Diane Lapp state, "We selected Children's Writing for the series because never before has such an exhaustive study been undertaken to examine the writing processes and teachinglearning strategies of elementary school children and their teachers. In the past, most large-scale reviews have been limited to secondary school, college, or adult writers." An examination of the research on peer tutoring by the author found that peer tutoring in writing skills was described frequently at the college level in writing lab situations, but not with younger subjects. 
Collaborative writing and cooperative learning are mentioned frequently in the research on writing instruction, but the emphasis here is on working jointly to create a product together or to improve the writing of each group member. In this study, the purpose of the peer tutor is to develop the writing skills of the younger tutee with the expectation that the experience will benefit both tutor and tutee (Topping \& Whiteley, 1993).

The second purpose is to see if the tutoring, for which the main purpose is the improvement of process writing skills, will impact reading. Literacy specialists recognize the integral relationship among reading, speaking, listening, and writing that helps in the constructing of meaning and information from one another. Written language is learned in meaning-centered, functional ways, and reading and writing are learned from whole to part by engaging in the processes themselves (Shanahan, 1984; Tierney \& Pearson, 1984; Goodman, 1986; Langer, 1986; Harste, Short, \& Burke, 1988; Routman, 1996).

The third purpose will be to research the effects of peer tutoring on the attitudes about writing and selfperceptions of themselves as writers of all the students involved in the study while looking to see if there are 
differences in tutored and non-tutored students. This is important to know because children's attitudes play a significant role in their literacy learning.

In summary, these three purposes support the aim of this study to examine cross-age peer tutoring as a potential method of improving all of the skills associated with process writing and reading skills, as well as the attitudes toward writing and self-perceptions as writers of everyone involved in the project.

\section{Statement of the Problem}

This study is designed to investigate the impact of cross-age peer tutoring on the writing and reading skills and their attitudes about writing and their selfperceptions as writers of third and fourth grade students. The following represent questions to be addressed in the study:

1. Can growth in writing skills be attributed to the crossage peer tutoring?

2. Can growth in reading skills be attributed to the crossage tutoring?

3. Will the attitudes of the students, be positive toward writing and themselves as writers? 
The details of this research will be presented in the subsequent chapters of this dissertation. Chapter II of this dissertation is a review of the literature relevant to the study. Chapter III contains a detailed explanation of the design and the specific hypotheses to be tested for this research. Chapter IV is an interpretation of the results of the research. Chapter $V$ contains a general discussion of results and suggestions for further research, as well as practical applications of this research.

\section{Assumptions}

It is important as researchers to identify assumptions that may influence the results and interpretations of a study. Among the assumptions considered for this study are:

1. The pretest and posttest scores of the subjects are assumed to typify their abilities.

2. The time allotted for this study is adequate to record changes in both writing and reading skills.

3. The measurement instruments would be adequate to measure writing, reading, attitudes, and selfperceptions. 
The following limitations have been identified as related to this study:

1. Students' performance in this study may have been influenced by prior experience in the writing process.

2. Students were not randomly assigned to groups. Existing classroom groups were used in the study. Because of the modified experimental nature of this study, generalizability may be limited.

3. Both the fourth grade tutoring (EC) group and the fourth grade non-tutoring (CC) group were taught language arts by the same teacher; the author of this study. This fact may limit the impact of the treatment.

4. Caution should be taken in extrapolating the results since there were a limited number of subjects in each group and the students were all above average and gifted.

Definition of Terms

For the purposes of this study these terms were defined as follows: 
COLLABORATIVE LEARNING: learning by working together in small groups, so as to understand new information or to create a common product

CONVENTIONS OE WRITING: refers to punctuation, capitalization, spelling, and variation in sentence structure

COOPERATIVE LEARNING: any pattern of classroom organization that allows students to interact to achieve their academic goals

CROSS-AGE PEER TUTORING: sometimes called "peer tutoring" occurs when an older child tutors a younger child EOCUS: refers to how clearly a writing sample presents and maintains a main idea, theme, or unifying point GIETED: having special talents or skills; in this study, it refers to the students who have been formally tested and staffed by a placement specialist into a special two day a week pull-out program for students who need enrichment.

HOLISTIC SCORING: a method by which trained readers evaluate a piece of writing for its overall quality. (For example, the holistic scoring used on the Florida Writes! Test requires readers to evaluate the work as a whole, while considering four elements: focus, organization, 
support, and conventions. This method is sometimes called focused holistic scoring. In this type of scoring, readers are trained not to become overly concerned with any one aspect of writing but to look at the response as a whole.)

MOVIES IN MY MIND: a writing response group technique, developed by Peter EIbow (1973, 1998), in which the Iisteners describe what each pictured in his/her mind as he/she heard the write read out loud

ORGANIZATION OF WRITING: refers to the structure or plan of development of a piece of writing. It also includes the use of transitional devices, and evidence of connection between sentences

PEER: a person with the same rank, ability, or qualities of another

POINTING: a writing response group technique, developed by Peter Elbow (1973, 1998), in which the listeners point out powerful/effective words or phrases in their partners orally-presented writing

PROCESS WRITING: a writing instruction model that views writing as an ongoing process and one in which students follow a given set of procedures for planning, drafting, revising, editing (proofreading and correcting), and publishing (sharing by some means) their writings 
PULLOUT PROGRAM: an enrichment program in content areas, which removes students from the regular classroom for instruction for specified amounts of time

RUBRIC: the carefully developed criteria for scoring a piece of writing, or other written work. (For example, the rubric for the Florida Writes! Test contains eleven possible scores and interprets the four major areas of consideration into levels of achievement.)

SCAFEOLDING: help provided to the learner from a more experienced person, which allows the learner to achieve more than he/she would achieve alone; help is withdrawn as the learner becomes independent

SUMMARIZING: a writing response group technique, developed by Peter Elbow (1978, 1998), in which the listeners summarize the writing in one sentence of their own and choose one word from the writing which best summarizes the write, followed by one word of their own selection that summarizes the piece of writing SUPPORT: refers to the quality of details used to explain, clarify, or define in a piece of writing. The quality of support depends on word choice, specificity, depth, and thoroughness

TUTEE: a person being tutored 
TUTOR: the act of giving special or individual instruction; to teach; instruct. A person who tutors another

ZONE OE PROXIMAL DEVELOPMENT: the distance between a child's actual developmental level as determined through independent problem solving and potential development as determined through problem solving under adult guidance or a collaboration with more capable peers (Vygotsky, 1978) 
CHAPTER TWO

REVIEW OE THE LITERATURE

The purpose of this chapter is to present a review of literature relevant to this study. These areas include:

(a) history of language arts $\mathrm{k}-12$, (b) research in writing,

(c) writing instruction, and (d) cross-age peer response groups.

A History of Language Arts $\mathrm{k}-12$

This section offers theoretical and historical perspectives to aid in the understanding of how the teaching of the English language arts has become what it is today. Understanding these perspectives helps to contextualize the need for the current study.

Early in this century, readers and independent spelling programs formed the popular core of elementary school curriculum in language arts. Textbooks focusing on penmanship, manuscript form, and elements of grammar and usage did not appear until later (Burrows, 1955). In the late 1930s, talk began within the National Council of Teachers of English about the project method and about integrating the language arts into "meaningful" classroom activities, about "functional teaching" of English, and about correlating English studies with those in other 
subjects. However, isolated instruction in reading, grammar, literature and writing continued for the next 50 years (Squire, 1991).

Two decades later, in the 1950s, the term "language arts" became popular in the profession among elementary school teachers because it suggested the integration of skills and experiences. Today, the concern with whole language and the integration of reading and writing continues as a curriculum concern (Squire, 1991).

The omission of English from the National Defense Education Act of 1958 (NDEA) led the National Council of Teachers of English to lobby vigorously for English to be included. It was not until October 1964, that Congress extended NDEA to include English and reading. It was at this time that Project English was established by the Cooperative Research Branch of the U. S. Office of Education. Project English was designed to "sponsor an increasing amount of research and experimentation in the area of English instruction." These projects were only funded for five to seven years (Early, 1991).

It was the mid-1960s before composition was stressed below the high school level and only since the 1980 s has writing shared a priority with reading in the primary 
school (Chall, Conard, \& Harris, 1977; Graves 1978). The Conference on College Composition and Communication (CCCC) served as a national center within the teaching profession for those concerned with the teaching of writing throughout the K-college curricula. Leaders of the CCCC were responsible for the publication of The state of Knowledge About Composition in 1963, a review of research which forcefully rejected grammar-based approaches in improving children's writing (Braddock, Lloyd-Jones, \& Schoer, 1963). Members of this organization lobbied vigorously for stronger preparation of high school and elementary school teachers in writing (Committee on National Interest, 1961, 1964).

James Britton's research on composition has most strongly affected the English curriculum, especially in elementary and middle schools. Britton's ideas are presented most completely in two works, Language and Learning (1972) and The Development of Writing Abilities (11-18), (Britton, Burgess, Martin, McLeod \& Rosen, 1975). According to Britton (1972), the process of composing in writing should be wedded to that of reading, and both should be related to the students' spoken language ( $p$. 159). Elementary teachers should not use graded readers, 
which isolate "sight vocabulary" from the child's speech vocabulary. The latter should be fully developed in beginning reading through having the child either dictate or write selections (p. 162).

The Development of Writing Abilities (11-18), a report completed by Britton, et al. in 1975, has been purported to be "undoubtedly the most influential study in writing across the curriculum in the last fifteen years" (Kinneavy, 1987, p. 361). The researchers' conclusions were based on 2,122 collected and analyzed "scripts" or pieces of writing by 500 students between the ages of 11 and 18 from 1967 and 1971.

Britton's emphasis on the importance of expressive language has influenced the uses of informal discussion, "brain-storming" techniques, free writing, and journal writing in American schools. Also, his belief that students need to write for audiences other than the teacher has encouraged the practice of peer editing and writing for varied audiences. He is also credited, in part, for the idea that students be given opportunities to take "ownership" of their writing by determining for themselves matters of content, audience, and purpose (Atwell 1987 ; Calkins, 1983; Graves, 1983b). 
An overview of reading and writing research from 1900 to 1984 (McCarthey \& Raphael, 1992) identifies three major perspectives of learning and development: (1) cognitive information processing theories; (2) Piagetian/Naturalist theories; and (3) Social-Constructivist theories, and their effect on literacy education. Beginning in the late 1970s, writing as a problem-solving cognitive task was explored by researchers and theorists. The most notable of these were Flower and Hayes (1980; Flower, Hayes, Carey, Schriver \& Stratman, 1986) and Scardamalia and Bereiter (1986). Cognitive Information Processing Theories

These cognitive information processing theorists seemed to be guided by three basic assumptions: (1) reading and writing consist of a number of subprocesses used to perform specialized tasks, (2) readers and writers have limited capacity for attention so that trade-offs occur across the subprocesses, and (3) competence in reading and writing is determined by the degree of attention needed to operate subprocesses; thus, the less memory needed, the more efficient the operation (McCarthey and Raphael, 1992). Newer research in reading and writing, the naturalists' perspective and the social-constructivist view of learning, rejects the problem-solving cognitive task 
perspective because of its characterization of the writing process as a solitary, individual process. More current representations of writing emphasize it as a socialinteractive activity with the social moves and roles inherent in any language activity (Nystrand, 1989).

This emphasis on innate language abilities and the role of the environment in allowing these abilities to unfold is consistent with holistic approaches to reading and writing. In these approaches, learning is both personal and social and is driven by the learner's need to make sense of the world (Goodman, 1967, 1986; Goodman \& Goodman, 1977; Harste, Woodward, \& Burke, 1984; Smith, 1983).

Based on the assumption that written and oral language share the same basic characteristics, the naturalists' perspective suggests that the development of reading and writing is like the acquisition of oral language. Goodman (1986) states that written and oral language develop naturally, moving from whole to part with no hierarchy of subskills. Meaning is acquired in the context of reading and writing, rather than learning to master specific skills or participating in formal instruction. 


\section{Piagetian/Naturalists Theories}

Three premises of Piaget"s theory of development are critical to this perspective: (1) thinking resembles logico-mathematical structures; (2) the child assumes an inherently active role constructing knowledge and continually trying to maintain equilibrium between herself and the environment: and (3) cognitive development depends on the learner acting upon the world (McCarthey \& Raphael, 1992).

Piagetian perspectives suggest that children learn oral and written language in order to accommodate and assimilate the print environment. Language use is functional; children can make sense of language when it meets real needs. This implies that children have strategies that develop over time as they experience language. These strategies include: (1) text intent, in which students expect text to make sense; (2) negotiability, students use what they know already to make sense of print; (3) risk-taking, students hypothesize about the meaning of print; and (4) fine-tuning, students use previously learned language in a new situation (Harste, Woodward \& Burke, 1984). 
In Piagetian theory, internal cognitive structures are formed as the child progresses through universal stages of development. As the result of interaction between the individual and the environment, changes occur in these structures. Holistic approaches incorporate this view of learning suggesting that reading and writing are natural processes that occur as a result of maturation and interaction with the language world. Social-Constructivists Theories

The roots of social constructivism are based on the theories of Vygotsky (1978, 1986; cited in Werstch, 1985) and others who have modified and developed his views (Bruner, 1985; Rogoff, 1986). There are three assumptions of the social-constructivist theory of human learning: knowledge is constructed through the individual's interaction with the sociocultural environment; (2) higher mental functions, including reading and writing, are social and cultural in nature; and (3) knowledgeable members of a culture can help others learn.

The social-constructivist position emphasizes that reading and writing are connected through their uses within the culture and through the role dialogue plays in the development of literacy. Knowledge is constructed by the 
interactions of individuals within society; all thought is social in nature (McCarthey \& Raphael, 1992). Vygotsky (1978) has shown that people internalize language from social interactions. Halliday (1978) describes language as the medium of human learning. Language allows people to share their experiences and insights and pool their intelligence. Halliday (1984) concludes that as we learn language we learn through it.

Vygotsky (1986) characterizes reading and writing as mental functions that require voluntary self-regulation, conscious realization, and the use of signs for mediation. He describes such learning as first occurring between people and then within the individual. It is through speech and social interaction that the learner acquires new abilities. Vygotsky suggests students learn about the functions of print and the conventional forms that allow print to communicate through interaction with a more knowledgeable adult or peer. It is through the modeling and thinking aloud of the more expert person that students learn.

The "zone of proximal development" (ZPD) used by Vygotsky characterizes how learners develop higher mental functions. He defines the ZPD as the "distance between a 
child's actual developmental level as determined through independent problem solving and potential development as determined through problem solving under adult guidance or a collaboration with more capable peers" (Vygotsky, 1978 , p. 86). Assumptions related to the ZPD are: (1) there is a difference between what the child can accomplish now and his or her potential for further learning; (2) what can be achieved alone is different from what can be achieved with the help of a knowledgeable adult or peer; and (3) a deliberate transfer of control from the more knowledgeable to the less knowledgeable person takes place. This help, provided to the learner by the more expert individual to accomplish a particular task, is referred to as "scaffolding."

Palinscar and Brown (1986) used Vygotsky's construct of expert scaffolding and zone of proximal development to develop a program of reciprocal teaching of reading comprehension strategies. There is much support for instructional programs where students find themselves doing more than they expected because the right kind of help was provided. Both naturalists and social constructivists advocate many current practices in creating a literate environment and providing social interaction in literacy 
learning. Gunnarsson (1997) argues, from a sociolinguistic perspective, that the writing process needs to be viewed from the perspective of the group doing the writing looking at the social dynamics and the way writers function as a community.

The three perspectives (information processing theory, naturalist theory, and social constructivism) suggest different ways in which reading and writing relate. Information processing theory matches individual components of reading and writing to imply the connection between the two. The naturalist theory connects reading and writing by proposing that both naturally connect through oral language. Social constructivism suggests that links between reading and writing need to be made by a knowledgeable member of a culture through dialogue and directed activities. Each of these perspectives has contributed to an understanding of different aspects of literacy processes and their interrelationships.

\section{Research in Writing}

Research on the writing process, which began in the late 1970s, focused on planning and revising, the cognitive processes involved in writing. Research in the 1980 s and 1990s has been more concerned with particular writing 
contexts, such as the classroom, and has emphasized the social processes involved in composing.

Research shows the importance of writing as a way of learning and as an integral part of classroom life (Calkins, 1983; Graves, 1983a; Murray, 1984; Tway, 1984). Lucy Calkins (1983) stated that she started out her research in writing, purposely ignoring reading, because reading had had so much attention for so long. She found she could not ignore reading, since reading enhances writing. Tway (1985) writes, "As glad as teachers of writing may be to see writing getting new respect they will want to guard against viewing writing in isolation" (p.1). Goodman and Goodman (1983) advise that "people not onIy learn to read by reading and write by writing but they also learn to read by writing and write by reading" (p. 592). Recent research begins to examine reading and writing as processes, the interaction of reading and writing processes, and ways to integrate their instruction. Shanahan (1984) and Shanahan and Lomax (1986) found reading interacts with writing. They identified components of the reading and writing processes and examined the changes in the knowledge structures underlying successful literacy learning as students abilities developed. In a review of 
the literature examining reading/writing connections, Stotsky (1983) found that generally better writers tend to read better and that better readers tend to produce more syntactically mature writing than poor readers. This connection between reading and writing is fairly new in the research. In fact, the inclusion of process writing instruction in the language arts curriculum is also a relatively new idea. Inclusion of process writing instruction in the high school curriculum began in 1964, but writing has only been a priority in the elementary schools since the 1980s. Research in writing in elementary school remains an area needing study.

Writing Instruction

Research into the history of language arts instruction traces many curricular changes regarding reading and writing, especially in the elementary school. Howard Gardnex (1991) states, "It is heartening to report, therefore, that classes filled with student writing and "prewriting" exemplify what is probably the major change in American elementary education over the past quarter century" (p. 211).

This research also indicates that much more attention needs to be given to finding successful ways for students 
to become accomplished writers. The reports by the National Assessment of Educational Progress (NAEP) show that students, in general, do not receive enough writing instruction and not enough time is allotted in the school day for writing and revision (Gentile, 1992). Graves (1991) suggests four essentials for a successful writingprocess program: time to write, choice of topics, response to writing, and the establishment of a community of learners.

Donald Graves, in his book, A Fresh Look at Writing (1994), stresses that with so little time to teach in a school day, we have to decide what endures. Much has been learned about the essentials of teaching writing and how to use time more effectively through the ongoing research in the field. He points out that every study that he has conducted over the past ten years has shown that what the children can do has been underestimated. Also, he now feels that teachers need to be more assertive, while Iistening to children, and know when to step in, when to teach, and when to expect more from our students. He points out that it has taken him years in the field to realize that the real purpose of writing is to help 
students to learn to think through the issues and concerns of their everyday lives.

Graves (1994) emphasizes that it is of extreme importance to teach children to read their own writing. Without the skills necessary to take knowledgeable responsibility for reading their work, writing will not improve. He also sees peer response as a necessary ingredient in helping writers rework their own text. Writing is a social act. Vygotsky (1978) has shown that people internalize language from social interactions, and Halliday (1984) concluded that we learn through language while we learn language.

Teachers need to teach the specific skills children need to read and share their own writing. This teaching of specific skills shifts the responsibility for their writing to the children, while helping them become capable lifelong writers. Boyle and Peregoy (1990) suggest "literacy scaffolds" that students can use in improving their writing. Peyton, Jones, Vincent \& Greenblatt (1994) suggest supports that will promote writing fluency. These include:

- Talking and writing extensively. 
- Encouraging lots of reading and writing in response to that reading. Graves (1994) suggests combining the teaching of literature with writing, especially with older students.

- Giving mini-lessons and modeling writing for students, while encouraging many different types of writing.

- Providing topics, vocabulary and verb lists.

- Writing within a thematic unit (Atwel1, 1987; Calkins, 1991).

- Encouraging children to say more, be more detailed, sustain their work longer (Calkins, 1994).

The improvement of writing instruction is an important component in the quest for the improved writing skills and attitudes towards writing of elementary school students. According to Donald Murray (1987), "Revision is one of the writing skills least researched, least examined, least understood, and usually-least taught" (p. 85). Sommers (1980) found that inexperienced writers often have an "inability to 'review' their work again. . with different eyes" (p. 382). Harper (1997) observed that in her relatively successful seventh grade writing workshop, revision was the one area of the writing process that her students did not know how to do. Her students did not seem 
to have the success described in Nancie Atwell's (1987) In the Middle and Linda Rief's (1992) Seeking Diversity. She discovered "that student conference partners didn"t hear or couldn't articulate the weaknesses in each others' writings" (p. 193).

Harper began using some student questioning techniques in her writing workshops. The techniques described in her article are similar to those recommended by Peter Elbow (1973, 1998), whose techniques were used in this study. Harper's students began to experience what Murray (1987) refers to as "a process of discovery." He asserts that "writers much of the time don't know what they are going to write. . [and they] use language as a tool of exploration to see beyond what they know" (p. 90). The questioning techniques reinforced this idea in Harper's (1997) classroom.

Peter Elbow (1998) states in the introduction to the second edition of his book, Writing Without Teachers, that after writing the first edition of this book, he came to the conclusion that everyone wants to write. He says, over the years I've come to see this situation in its stark factual simplicity: 
- Little children of four, five, and six write eagerly and with pleasure if they are simply encouraged to do so and helped to finesse the problems of spelling and correctness (see Calkins, 1986; Graves, 1983b). They love it and find it easy.

- Almost everyone by the time they have finished high school comes to dislike or fear writing and to avoid it whenever possible.

- And yet a desire to write still lurks in almost everyone. I guess I got the title right: "Writing Without Teachers." Teachers seem to play a big role in making it harder for people to write. Yet they can't quite stamp out the desire (pp. xi-xii).

Elbow (1998) argues that students can get along without teachers if they have a group of people sharing their experiences with each other. He cites two main things that can be done to get or test trustworthy knowledge: doubting and believing. He defines "doubting" as criticizing, debating, arguing, and trying to extricate oneself from any personal involvement with the ideas by 
using logic. "Believing" is defined as listening, affirming, entering in, trying to experience more fully, and restating-understanding ideas from the inside. In Elbow"s "teacherless writing groups" it is the "believing" strategy that is emphasized. He believes that writers cannot see the weaknesses in an idea by looking for weakness. The weaknesses do not show up until the writers look for strengths in ideas. Because of the focus on process writing where the author's message and the mechanics both contribute to meaning, research into the ways that writers support writers is suggested in this body of literature seems to present itself as a rich area of focus.

Cross-Age Reer Response Groups

The cognitive approach to writing has met with a great deal of criticism when contrasted with the newer emphasis on the social nature of writing (Eaigley, 1986; Nystrand, 1986, 1989). Ianguage learning depends on social interaction (Johnson \& Johnson, 1975). This learning is dependent on a classroom environment that encourages and engages students in social interactions that allow them to modify their cognitive structures and construct their own knowledge (Hoskisson \& Tompkins, 1987). 
This concept of social learning and the newer concepts of what it means to teach literacy are more complex than those of the past, and reflect a shift to a social constructivist view of human learning (Butterworth, 1993; Cole, 1996; Doyle 1990). We are seeing a change in the traditional view described by Damon and Phelps, "Virtually all schooling, in this country and elsewhere, is structured around the traditional belief that knowledge is best transmitted from adult to child in a linear fashion" (1989b, p. 136). Swengel (1991) also contends that the basic instructional unit of teacher-and-class has been the fundamental problem with formal schooling for thousands of years. He proposes that "Mutual Instruction," his term for peer and cross-age tutoring and counseling, is the solution to this problem.

A growing interest in our schools today is to promote peer interaction through cooperative learning, small group activities, and peer tutoring. This is largely in response to Vygotsky's principle that social interaction serves as a catalyst for intellectual growth. According to Vygotsky, mature thinking is largely inner speech and dialogue representing the end product of a developmental process that begins with external speech with adults and peers 
(Vygotsky, 1962).

Marie M. Clay (1991) stated that current analysis of Vygotsky's work is not focused on his concept of inner speech. It is focused partially on his social theory and mostly on his concept of the zone of proximal development. He challenges current teaching practices because he sanctions shared activity between tutor and learner so that the learner can complete more difficult tasks with help than he would alone. The help of the expert becomes unnecessary, as the learner is able to perform the entire task.

Slavin (1980) defines cooperative learning as a technique "in which students work on learning activities in small groups and receive rewards or recognition based on their group's performance." Peer tutoring differs from cooperative learning in that in peer tutoring one child is instructing another. Peer tutoring is defined by Damon and Phelps as "an approach in which one child instructs another child in material on which the first is an expert and the second is a novice" (1989a, p.11).

There are multiple definitions of peer tutoring, which are not all consistent. Not all peer tutors are selected because they are "experts." Often tutors are randomly 
assigned, same-age classmates (Greenwood, Delquardi, \& Ha11, 1989; Palincsar and Brown, 1986) or same-aged low achievers (Pigott, Fantuzzo, \& Clement 1986). Gaustad (1993) explains: "Peer tutoring occurs when tutor and tutee are the same age. In cross-age tutoring, the tutor is older than the tutee. However, sometimes the term peer tutoring is used to include both types" (p. 1).

One of the most comprehensive reviews of peer tutoring, a meta-analysis of 65 studies conducted by Cohen, Kulik, and Kulik (1982), reviewed 52 achievement studies. The investigators found that in 45 of the studies, the tutored programs had a moderately beneficial effect on achievement versus the untutored programs. The effect on attitude towards the subject matter was smaller, but significant. Math effects were stronger than reading effects for both tutors and tutees. The researchers found, when looking at the effects on tutors, a small but significant effect for academic outcomes and for selfconcept and a slightly larger effect for attitudes toward subject matter.

Because children's literacy learning is significantly influenced by their attitudes, values, 
beliefs and motivation, the affective domain is an important area of interest for educators and researchers (Cramer \& Castle, 1994; Turner \& Paris, 1995). Instructional practices for reading and writing have not benefited greatly from research in this area, especially affective instrumentation that focuses on the writing process (Bottomley, Henk, \& Melnick, 1997/1998).

According to Bandura's $(1977,1982)$ theory of perceived self-efficacy, a child's self-perception of writing ability will affect his/her subsequent writing growth. When applied to writing, the basic self-efficacy model suggests that individuals take four basic factors into account when estimating their ability to express themselves in print. These factors are: (a) Performance (a category that includes past success, amount of effort necessary, the need for assistance, patterns of progress, task difficulty, task persistence, and belief in the effectiveness of instruction): (b) Observational Comparison (how a child perceives his/her writing performance in relation to peers); (c) Social Feedback (direct and indirect input about the child's writing derived from teachers, classmates, and family members); and (d) 
Physiological states (internal feelings that the child experiences during writing). Bandura (1977, 1982) predicts that individuals who have positive writer self-perceptions will probably pursue opportunities to write, expend more effort during writing, and demonstrate greater persistence in seeking writing competence.

Other benefits, besides increased cognitive development and improved attitude toward subject matter, have been identified in studies on peer and cross-age peer tutoring. Levin, Glass, and Meister (1987) found that peer tutoring was more cost-effective than Computer Assisted Instruction, reducing class size, or lengthening the school day. These findings provide important evidence of practical reasons to include peer and cross-age peer tutoring in school curriculums.

Students need a classroom environment that encourages and engages students in social interactions that will allow them to modify their cognitive structures and construct their own knowledge. Newer research in reading and writing stresses the social-interactive nature of learning; finding learning to be personal and social in nature and driven by the learner's need to make sense of the world. There is a growing interest in today's schools to promote peer 
interaction through cooperative learning, small group activities, and peer tutoring.

This study is intended to build on the body of Iiterature reviewed in this chapter by exploring the effect of cross-age peer tutoring on the writing skills of third and fourth grade students. Because of the reciprocal nature of reading and writing, the study will also explore the effect of cross-age peer tutoring on reading achievement scores. The third area explored for the effects of cross-age peer tutoring will be the students' attitudes toward writing and their self-perceptions as writers. 
CHAPTER THREE

METHODS

The purpose of this chapter is to present: (a) a description of the research context, (b) an overview of the study, (c) the research design, (d) hypotheses, and (e) procedures and methods.

\section{Description of the Research Context}

This research was conducted in four established classrooms in a public school. Research using authentic classrooms, instead of strictly controlled scientific environments that allow for pure experimental designs, has benefits as well as limitations. Graves (1983a) argued that educators must stop pretending that we can transfer scientific procedures to what are essentially social events and processes. Research that ignores context-real episodes from real classrooms in real communities-does little to help us become better teachers for the students that fill our classrooms.

The main benefit of this authentic classroom research was the ability to see, for future reference, how this intervention, cross-age writing tutoring groups, would work with the population of the school in which the study was conducted. 
The elementary school used in this study is located in a suburban middle-class neighborhood in the southwestern part of Miami-Dade County. The student population statistics, at the time of this study, are itemized in Table 1.

Table 1

Student Ethnic Population $97 / 98$

\begin{tabular}{|c|c|c|c|c|c|c|c|c|}
\hline GRADE & MALES & FEMALES & WHITE & \multicolumn{2}{|c|}{ BLACK } & HISPANIC & \multicolumn{2}{|c|}{ OTHER } \\
\hline & TOTAL & TOTAL & TOTAL $\frac{\circ}{0}$ & $\mathrm{TO}$ & IL & TOTAL & TOT & I \\
\hline $\mathrm{KG}$ & 7444.0 & 9456.0 & 3420.2 & 12 & 07.1 & 10964.9 & 13 & 07.0 \\
\hline 01 & 9851.3 & 9348.7 & 4925.7 & 12 & 06.3 & 11962.3 & 11 & 05.8 \\
\hline 02 & 10654.1 & 9045.9 & 4824.5 & 14 & 07.1 & $120 \quad 61.2$ & 14 & 07.1 \\
\hline 03 & $114 \quad 54.6$ & 9445.2 & 4521.6 & 13 & 06.3 & $138 \quad 66.3$ & 12 & 05.8 \\
\hline 04 & $119 \quad 3.4$ & $104 \quad 46.6$ & 4922.0 & 12 & 05.4 & 15167.7 & 11 & 04.1 \\
\hline 05 & $136 \quad 61.5$ & 8538.5 & 4922.2 & 10 & 04.5 & $153 \quad 69.2$ & 9 & 04.1 \\
\hline TOTAL & 64753.6 & $560 \quad 46.4$ & $274 \quad 22.7$ & 73 & 06.0 & $790 \quad 65.5$ & 70 & 05.8 \\
\hline
\end{tabular}

The 122. students, 61 females and 61 males, involved in this study included 56 third grade students and 66 fourth grade students. The tutoring groups included 65 students and the non-tutoring groups contained 57 students. There were 53 students in the two grade levels who were staffed into the gifted pullout program and 69 students who did not participate in the gifted program. A comparison of Tables 1 and 2 reveals the match between the total school population and the students who were involved in the study. 
Table 2

Ethnic Population of the Four Treatment Groups

\begin{tabular}{|c|c|c|c|c|c|c|}
\hline GRADE & MALES & EEMALES & WHITE & BLACK & HISPANIC & OTHER \\
\hline & TOTAL \% & TOTAL \% & TOTAL \% & TOTAL 8 & TOTAL \% & TOTAL \% \\
\hline 03 & 2824.5 & 2829.7 & 1533.3 & 0215.4 & 3323.9 & 0650.0 \\
\hline 04 & 3327.7 & 3331.7 & 1326.5 & 0758.3 & 3825.2 & 0872.7 \\
\hline TOTAL & 6126.2 & 6130.8 & 2829.8 & 0936.0 & 7124.6 & 1460.9 \\
\hline
\end{tabular}

The researcher was the classroom teacher for both fourth grade language arts groups in this study. It is acknowledged that the results could be confounded by this fact. The decision was made to control the instruction in both fourth grade treatment groups to avoid confounding variables by having different teachers i.e. varying experience, different teaching styles, and knowledge level of the teachers. Additionally, the benefits of research using authentic classrooms lead to the final decision to use both fourth grade language arts groups in the study.

Two different teachers taught language arts to the two third grade classrooms (treatment groups). As with the two fourth grade classes, it was determined by the administration of the school that the two third grade classes were matched in population: gifted and upper stanine students. 
Overview of the study

Before the eleven-week intervention began, a writing pretest sample was taken from all third and fourth grade students in the study before any training or treatment began. Two evaluators, trained and certified by the state of Florida to score the fourth grade Elorida Writes! Test, were hired to score the pretest writing of the fourth grade students and the pretest and posttest writings of the third grade students involved in the study.

During the first month of school the fourth grade students in the tutoring group (EC), were trained to work in writing groups using the organization and three of the techniques suggested by Peter Elbow in his book Writing Without Teachers $(1973,1998)$.

The eleven-week intervention began after the first week of pretesting and the three weeks of tutor training. Students worked in groups of four to six people, meeting for one hour a week. During the tutoring periods, the teacher (researcher) walked around the classroom observing the groups.

Each tutoring session followed the same format. Each member of the group read his/her writing for the week twice 
orally to the group, with a break between readings. All of the members of the group then responded to the writing using the assigned response technique.

Three response techniques recommended by Elbow 11973, 1998) were used. The technique used during the first month of the study is what Elbow identifies as "movies in my mind." In this technique, each member of the group, after hearing the author read the piece twice, explained what he/she was able to picture in his/her mind.

The technique that was used during the second month of the study is called "pointing." After hearing the author read the piece twice, each group member pointed out words and phrases that seemed the most successful, and one word from the author's writing that seemed to describe the writing in the view of the listener. Each listener also offered a word of his or her own to describe the writing. "Summarizing" was the third technique, used during the last three weeks of the study. Each Iistener, after hearing the author read the piece twice, chose one sentence and one word from the piece of writing and offered one word of his/her own that best summarized the work.

At the end of the experimental treatment, an attitude survey, the Writer Self-Perception Scale, (Bottomley, et 
al., 1997/1998) was administered to measure the effects of the treatment on the students' attitudes toward writing and students' self-perceptions of their writing ability.

Quantitative data were used to measure effects of the peer tutoring on reading, and the score each participant earned on the Florida Writes! Test was used as a posttest score to measure his/her writing growth. The third grade students' final writing samples were scored by the two state-trained and certified evaluators who scored all of the pretests for this study.

\section{Research Design}

The research design used the basic approach of a oneway ANOVA with linear contrasts analyzing the gain scores of four treatment levels: fourth grade tutors, third grade tutees, fourth grade non-tutoring, and third grade nontutoring groups. Three linear contrasts, derived from the ANOVA, were used to answer three questions.

1. Did gain scores differ for third and fourth grades?

2. Did gain scores differ for tutoring and nontutoring?

3. Was there an interaction between tutoring and grade level? 
The design was selected to test the hypotheses of the study.

Hypotheses

With these research questions in mind, the following experimental hypotheses were investigated:

Hypothesis 1: Both cross-age peer tutoring groups will have higher writing gain scores than the students who receive regular instruction only.

Hypothesis 2: Both cross-age peer tutoring groups will have higher reading comprehension gain scores than the students who receive regular instruction only.

Hypothesis 3: Both cross-age peer tutoring groups will have higher mean attitudes towards writing and writers' self-perception scores than the students who receive regular instruction only.

The treatments to test these hypotheses were two experimental cross-age peer groups: a fourth grade class who participated as the tutors; and a third grade class who participated as the tutees. The control condition consisted of a class of third grade students and a class of fourth grade students. The control groups were matched in ability levels to the two experimental groups. 
Because this research used classes that had been already created for a specific purpose in a public school, complete random assignment was not possible. Enroliment in these four classes had been decided by the school administration to support the academic needs of identified gifted students and of students in the upper stanines who would function in a blended gifted/regular classroom. The research design was a modified experimental design applied to convenient samples. Because subjects had already been assigned to classes, the students in the third and fourth grade classes were randomly assigned to either tutoring or non-tutoring groups (see Procedures Section). The study used a modified experimental design, as described by cook \& Campbel1 (1979) and Gay (1996).

Tutoring (Experimental Condition)

The experimental condition (EC) consisted of the implementation of a structured program of cross-age peer writing response groups. The children were randomly assigned to writing response groups while making sure that the groups were balanced for gifted and regular instruction members (see Appendix A). The intervention was administered by the researcher, who was the classroom 
teacher, to the tutoring groups throughout an 11-week period involving one sixty-minute session a week. Non-tutoring (Control Condition)

The control condition (CC) consisted of the regular classroom curriculum as mandated by the Miami-Dade County Public Schools. Language arts and reading instruction were held constant for the fourth grade tutoring and nontutoring groups. The only difference in the instruction for the two groups was the weekly one-hour cross-age tutoring intervention. This strict control was possible because the researcher was the reading and language arts teacher for both groups. This resulted in a teacher intervention, which will be discussed later as a part of the results. The two third grade groups had different teachers.

The research question was stated as such: What is the impact of cross-age peer tutoring on the writing and reading comprehension skills, the students' attitudes about writing and self-perceptions as writers of third and fourth grade students preparing for the Florida Writes! Test?

\section{Procedures and Methods}

The multiple dependent variables for the study consisted of the two gain score measures and the affective measure of the Writer Self-Perception Scale (Bottomley, et 
a1., 1997/1998). The study compared the performance of the four treatment groups on the dependent variables following eleven weeks of the cross-age peer tutoring response groups intervention in the tutoring group.

While the actual intervention, cross-age peer writing response groups, lasted eleven weeks, primary data collection took place over a twenty-week period. Writing pretests were administered during week one and the writing posttest was administered during week sixteen. The Stanford Achievement Test (1997) reading comprehension pretest scores, and the stanford Achievement Test (1998) reading comprehension posttest scores were used as measures for reading comprehension improvement.

Table 3

Timeline of the Study and Data Collection

\begin{tabular}{|c|c|}
\hline WEEK & ACTIVITY/DATA COLLECTED \\
\hline 1 & Writing Pretest administered to all groups \\
\hline $2-4$ & $\begin{array}{l}4^{\text {th }} \text { grade Tutor Group introduced to the } 3 \text { response } \\
\text { techniques. Researcher observed to be sure tutors } \\
\text { were ready to use techniques with third grade } \\
\text { tutees. }\end{array}$ \\
\hline 4 & $\begin{array}{l}\text { Researcher randomly assigned tutors and tutees to } \\
\text { groups. }\end{array}$ \\
\hline 5 & Cross-age writing response groups began. \\
\hline $5-8$ & Response technique "movies in my mind" was used. \\
\hline $9-12$ & Response technique "pointing" was used. \\
\hline $13-15$ & Response technique "summarizing" was used. \\
\hline 16 & Writing Posttest administered to all groups. \\
\hline 17 & $\begin{array}{l}\text { Writer Attitude and Self-Perception Test } \\
\text { administered to all groups. }\end{array}$ \\
\hline 20 & Reading Posttest administered to all groups. \\
\hline
\end{tabular}


The Stanford Achievement Test for 1998 was given to all four classes at the same time in week twenty. The Writer Self-Perception scale (Bottomley, et al., 1997/1998) was administered in week seventeen, one week after the Florida Writes! Postest. Table 3 gives an overview of the timeline of the study and the data collection points. Statistical Analyses

The main statistical analysis was concerned with the effect of the treatment on the dependent variables. In order to determine whether the independent variable had an effect on the dependent variables, Analysis of Variance (ANOVAS) with linear contrasts were run on the posttest scores and on the responses to the Writer Self-Perception Scale (Bottomley, et al., 1997/1998). (See Appendix B). Cross-tabulations were done on improvement level, treatment group, grade level, and gifted or not gifted to determine if there were any significant differences in at least two groups.

Subjects

The subjects of this study were 122 students in four existing elementary classrooms: two third grades and two fourth grade groups at Dr. Gilbert L. Porter Elementary School. The classes were formed by the school 
administration. All four groups contained the students staffed, recommended, or identified as potentially eligible for the school's resource gifted classes. The rest of the students were placed in the group to create a normal-sized class based on Dade County Public Schools' student-teacher ratio. Attention was given to the most current stanford Achievement Test scores of those students not in the resource program to insure that these students would not experience difficulty and frustration working with gifted students. There were no identified learning disabled or ESOL students in any of the four groups.

Permission

Permission to conduct this study was obtained first from the school site principal and then by written proposal from Florida International University and the Office of Educational Accountability of the Miami-Dade County Public Schools (See Appendix C). Subsequently, a permission letter was sent home, in English and in Spanish, to allow the students to participate in the study (See Appendixes D and $E$ ).

The students in all four groups were pretested at the beginning of the study. The pretest consisted of an equal 
number of a narrative prompt and an expository prompt that had been previousiy used on the Elorida Writes! Test (See Appendixes $E$ and $G$ ). These two prompts were randomly assigned to the students in all four groups. Two trained judges scored the writing pretests for all four groups in the study. The judges are certified by the Florida Department of Education to participate in the actual scoring of the state Florida Writes! Test. The Assessment Instruments

There were three assessment instruments used in this study. They will be described in detail.

Writing assessment. The Student Assessment Services Section of the Florida Department of Education reviewed the research on writing assessment and conferred with curriculum and writing consultants from states with established writing assessment programs. As a result, The Florida Writing Assessment Program adopted demand writing in 1990, considering it an effective method of assessing Elorida's fourth, eighth, and tenth graders (Bureau of Education Information and Assessment, 1994). With the assistance of an advisory group of teachers, district-level administrators, and citizens, the Department of Education 
developed the writing prompts, the scoring rubric, and selected papers to represent each possible score.

The Florida Writes! Test is given statewide on a date designated by the state Department of Education. The test is administered in a strictly timed 45-minute session, which includes reading the prompt, planning, and writing the one draft writing response. Students receive a writing folder containing a writing prompt and two lined pages for their written response. A separate planning sheet is provided for prewriting planning, which may include: mapping, clustering, outlining, number notes, or jotting down ideas.

At the fourth grade level students receive one of two randomly assigned prompts: one prompt is narrative and the other is expository. Students responding to a narrative prompt are required to tell a story about a personal or fictitious experience. Students responding to an expository prompt must give information, explain how or why, clarify a process, or define a process. The prompts are field tested and carefully selected to ensure that the subject matter is appropriate for the age of the students. Additionally, the prompts are reviewed for offensive or biased language relating to religion, sex, or racial or 
ethnic background (Bureau of Education Information and Assessment Services, 1994).

The writing responses were scored holistically by judges who have been trained to use an established sixpoint rubric to evaluate a writing sample for its overall quality (See Appendix H). Florida Writes! judges evaluate the work based on four elements: focus, organization, support, and conventions.

- Focus refers to how clearly the paper presents and maintains a clear main idea, theme, or unifying point. Papers judged to be at the high end of the six-point rubric, show a constant awareness of the topic and do not include any extraneous information.

- Organization is defined as the plan of development, or structure, of the piece and if the points are logically related to each other. Higher-end papers use transitional words and end with concluding, or summary statements.

- Support refers to the quality of the details used to support the main ideas and word choices to convey meaning.

- Conventions include punctuation, capitalization, spelling, and sentence variety. 
The six-point rubric (See Appendix $H$ ) interprets these four areas. Focus, organization, and support are judged as more important than conventions because of the timed nature of the test. The students do not have the opportunity for revision; the paper is judged as a rough draft. However, papers judged at the higher end of the rubric will have fewer errors in conventions than other papers.

The Florida Writes! scoring rubric (See Appendix H) has a maximum score of six points in one-half units 10,1 , $1.5,2.0,2.5,3.0,3.5,4.0,4.5,5.0,5.5,6)$ and the expected level of improvement for one semester of instruction is one point. The improvement levels were defined as "expected or less" for statistical analysis if the student had:

- a negative change in scores from the pretest to the posttest;

- a change of .5;

- or a change of one point. "More than expected" was defined as:

- an improvement of more than one point on the posttest. The posttest instrument in the study was the actual Florida Writes! Test for the fourth grade. The fourth grade tutoring (EC) and non-tutoring (CC) groups were 
administered the test under the strict testing guidelines of the state of Florida.

The next day, the same two prompts given to the fourth graders were randomly assigned to the third grade students. It was necessary to give the tests on separate days because the prompts are kept under strict test security rules until the actual testing session begins. The same two trained and state-certified judges who scored all four sets of pretests scored the third grade posttests. Reading comprehension assessment. Miami-Dade County Public Schools administer the Stanford Achievement Test in the spring of each year to measure students' achievement. The reading comprehension scores from the year of the study and the previous year's results were used as pretest/posttest measures.

Affective measure. One week after the writing posttests were given, the researcher administered, to the students in all four of the groups involved in the study, the Writer Self-Perception Scale (Bottomley, et al., 1997/1998). The Writer Self-Perception Scale (Bottomley, et al., 1997/1998) is based on Bandura's (1977, 1982) theory of perceived self-efficacy. In other words, the theory predicts that a child's perception of his/her 
writing ability will affect subsequent writing growth. This thirty-eight-item instrument is used to assess classroom writing climates and children's perceptions of themselves as writers. This instrument was administered as a posttest only, and not used as a pretest before the study began, because this Writer Self-Perception scale was published after the beginning of the study.

The questions on the writer Self-Perception Scale (Bottomley, et al., 1997/1998) are divided into five sections: General Progress (GP), Specific Progress (SP), Observational Progress (OP), Social Eeedback (SF), and Physiological states (PS). The eight General Progress Scale statements address students' perceptions of the act of writing being easier than it used to be. The seven statements in the specific Progress scale seek to elicit students' perceptions of their progress on the specific skills of better description, organization, and word choice. The nine Observational progress statements involve the students' comparison of their own writing skills to the other students in the group. The seven social Eeedback statements evoke students' perceptions of the feedback about their writing that they receive from family, friends and teachers. The six Physiological states statements are 
used to measure students' perceptions of how the act of writing makes them feel.

The basic self-efficacy model (Bandura, 1977, 1982;

Schunk, 1984) suggests that individuals consider four basic factors when estimating their ability to express themselves in print. These factors are:

- Performance - which includes past success, amount of necessary effort, need for assistance, patterns of progress, task difficulty, task persistence, and belief in the effectiveness of instruction;

- Observational Comparison - how a child perceives his/her writing performance in relation to peers;

- Social Feedback - direct and indirect input about the child's writing derived from teachers, classmates, and family members; and

- Physiological states - internal feelings that the child experiences during writing.

Bottomley, et al. (1997/1998) developed their selfperception scale to measure if there were any differences in groups in attitude towards writing or in the way students perceived themselves as writers (See Appendix B). 


\section{Experimental Procedures}

The following experimental procedures are organized by week and include preliminary information relative to that period of time. The total amount of time from the beginning of the study until the end was twenty weeks. The treatment intervention was preceded by four weeks of training and practice using the response techniques to be used in the study. The actual intervention, the cross-age writing response group sessions, took place for eleven consecutive weeks. The final assessment measure, the Stanford Achievement Test, was administered in Miami-Dade County Public Schools in week twenty.

The following reflect the experimental procedures:

1. The first week, students, in all four groups participating in the study, were pretested using the same two randomly assigned writing prompts.

2. The $4^{\text {th }}$ grade tutoring group $(E C)$, and the teacher spent a great deal of time during the first practice month setting up a community of learners. The students learned to collaborate, value, and respect each other through modeling and encouraging (Routman, 1996) in anticipation of the skills necessary for successful student-led writing conferences. 
3. The second practice week of the study, introduction of the necessary response strategies for the writing groups began. Students in the fourth grade experimental group were introduced to three writing strategies suggested by Peter Elbow (1973, 1998) to be used in teacherless writing groups. These strategies were introduced one at a time. After the initial introduction of each strategy, the rest of that week was spent practicing the new strategy while reviewing what had been previously introduced technique(s) in writing groups in the regular language arts class period.

4. The second practice week the students were introduced to and practiced the first technique of describing the "movies in my mind," or the pictures they saw as the author read his/her write. The routine of each piece being read aloud twice with a break between the readings was established.

5. The third practice week the students were introduced to and used the technique called "pointing," which involves pointing out words and phrases that they heard when the piece was read that they felt were especially good. 6. The fourth practice week the students practiced the technique called "Summarizing." When summarizing, the 
tutors listened to the piece being read and then pointed out a sentence from the writing that seemed to summarize the piece. Next, they stated a single word from the piece that they thought summarized the writing and a word of their own that they felt summarized the writing.

7. During the fourth practice week, groups of four or five students (two or three fourth grade tutors and two third grade tutees) were randomly formed (see Appendix A).

These groups were formed this way in an attempt to compensate for the fact that students within each group could not be perfectly matched, and to try to insure that the absence of a student would not result in a lost week in the study for that group.

Additionally, there were more students in the fourth grade tutoring group (EC) than there were in the third grade tutee group (EC). This configuration is a modification of Peter Elbow's suggested groups of seven to twelve. Elbow $(1973,1998)$ suggests two or two and one-half hours a week for teacherless writing groups. Because of the age of the participants and the school's schedule, only one hour a week could be dedicated to the cross-age tutoring sessions. This time constraint was another reason 
for the decision to make the groups smaller than the recommended seven to twelve.

Based on research into the issue of gender, an attempt was made to match the ability and gender of the tutor and tutee. Berliner \& Casanova (1986) suggest same-gender partners in both peer and cross-age pairs, for comfort and modeling reasons. Gender pairing is seen as especially important for girls (House, 1988; Pilen, Jason \& Olson, 1988; Rekrut, 1992; Evans, 1997). Rekrut (1994) found that cross-age tutoring is ideal for enrichment as advanced students gain experience in cooperation and understanding of students for whom learning is not easy. She also concluded that same gender partners work best at any age level. Fortunately, it was possible to configure groups in which all members of all groups were the same gender. 8. During weeks five through eight, the eleven-week intervention, cross-age writing response group sessions began. The response technique, "movies in my mind" (Elbow 1973, 1998) was used. The third graders easily modeled this technique.

The elementary school used in this study was involved in a daily-sustained silent writing time. A prompt was introduced at the end of morning announcements 
each day. Immediately following these announcements, there was a required fifteen-minute writing response time. One of these daily prompts from each week had been selected prior to the study to be the writing shared in the response groups (See Appendix I). This did not work as planned due to absences, schedule changes, and the length of the individual writes. Instead, the students shared any (or all) of their sustained silent writings from the previous week.

The original intent of the research was to have the tutees (the third graders) share their writing of the selected prompt for the week out loud and have the tutors (the fourth graders) respond using Elbow's technique. The enthusiasm within the groups altered this pattern. The fourth graders, used to sharing in their regular language arts class, wanted very much to share in the tutoring sessions. Likewise, the third graders seemed eager to hear the writing of their tutors. The routine became established that the tutees would share first to insure that there was adequate time for the prescribed responses. The fourth grade tutors would then share, time permitting, what they had written eliciting group responses 
9. Weeks nine through twelve - The response technique of "pointing" was added to the tutoring sessions. Pointing involves pointing to adjectives from the writing that describes the strengths of the piece. The third grade students, as a group, were not familiar with adjectives and their uses. A modification of the study was necessary. The researcher had to give a mini-lesson about describing words at the end of two sessions. After that, the students were more comfortable with the pointing strategy. The first strategy, "movies in my mind," continued to be a response technique in the cross-age peer groups, time permitting.

10. Weeks thirteen through fifteen - The response technique of "summarizing" was added to the tutoring sessions. This technique was the most difficult for the tutors and tutees. This strategy was only used for three weeks due to an unavoidable administrative delay in the start of this study. Most of the students, both third and fourth graders, were not strong in the skill of summarizing. The first two strategies continued to be used in the groups, as time allowed. 
11. A group report and sharing time concluded each tutoring session. The tutors were instructed to give a positive report of progress within their group.

12. Week sixteen-The posttest was administered to each of the four groups (See Appendices I and J). The fourth graders took the posttest on the date designated by the State Department of Education for Florida Writes! testing. The third graders were administered the test the very next day by the researcher.

13. Week seventeen-An attitude survey was administered to determine the attitudes of the participants toward writing and their perceptions of themselves as writers.

14. Pretest and posttest writing scores were analyzed. Stanford Achievement Test scores in reading from the previous year (1997) and from the test administered in week twenty, after the cross-age peer tutoring treatment ended (1998), were compared to measure any possible effects of the treatment on the reading skills of the participants.

15. It had been the intention of the researcher to look for effects of the treatment on the vocabulary and language mechanics scores of the students. However, Dade County Public Schools elected not to test those two sub-tests 
of the SAT in the 1997-98 school year; therefore, no data were available.

16. The researcher spoke with the two other homeroom teachers responsible for all of the children in the study on a regular basis. This was an attempt to be sure that there were no extraneous vaxiables that would interfere with the outcome of the study and to be sure that the teachers involved continued to have a positive attitude about their involvement. Observations about students' attitudes and progress were also shared between the teachers involved with the students.

This communication was necessary to ensure that the language arts instruction in the two third grade classrooms was fairly consistent. The researcher was the language arts teacher in both of the fourth grade classes involved in the study and was able to hold the writing instruction constant in both groups. The only variable was the crossage peer tutoring activity.

In summary, this classroom-applied research studied the effects of cross-age peer writing response groups on the reading and writing achievement of third and fourth graders. The reading comprehension subtests of the Stanford Achievement Test for third and fourth grades and 
the Florida Writes! Test for fourth grade were the measures used to analyze student achievement in these areas. The students" attitudes toward writing and their selfperception of themselves as writers were measured using the Writer Self-Perception Scale (Bottomley, et al., $1997 / 1998)$ 
CHAPTER EOUR

\section{RESULTS}

This study was intended to determine whether cross-age peer tutoring has an impact on the writing and reading skills and attitudes toward writing and self-perceptions of students receiving direct instruction in the writing process.

The data analyzed were based on the pretest and posttest scores of 56 third and 66 fourth grade student participants. Additional data were based on students' responses on a self-perception rating scale.

$$
\text { Effects of Variables }
$$

Effects of variables examined in this study were:

1. Writing gain scores (measured by a Elorida Writes! pretest and posttest)

2. Reading comprehension gain scores (measured by the Stanford Achievement Test reading comprehension subtest score)

3. Students" attitudes toward writing and their perceptions of themselves as writers (based on the five scales measured on the Writer self-Perception Scale, [Bottomley, et al., 1997/1998]). 
There were four treatment groups involved in this

study. The treatment groups were $3^{\text {rd }}$-grade tutoring group (EC), $3^{\text {rd }}$-grade non-tutoring group (CC), $4^{\text {th }}$-grade tutoring group (EC), and the $4^{\text {th }}$-grade non-tutoring group (CC). For the eleven weeks of the study, the tutoring groups received the regular language arts instruction and were involved in the cross-age tutoring response groups. The non-tutoring groups received only the regular language arts instruction.

\section{Analysis}

ANOVAs with linear contrasts were applied to the pretest and posttest writing scores of the Florida writes! Test and the Stanford Achievement Test reading comprehension sub-test scores for the 1996-1997 and the 1997-1998 school years. ANOVAs with linear contrasts were also done on the five sections of the Writer selfPerception Scale (Bottomley, et al., 1997/1998).

\section{Results}

The primary experimental research question addressed the issue of the relative effectiveness of cross-age tutoring in fostering the development of writing skills. Secondly, the possible existence of a relationship between cross-age writing tutoring groups and the development of reading comprehension was investigated. Thirdly, the 
possible existence of relationships between participation in the cross-age tutoring groups and students' attitudes about writing and their perceptions of themselves as writers were examined. The research question was stated as such: What is the impact of cross-age peer tutoring on the writing and reading skills, and the students' attitudes about writing and their self-perceptions as writers of third and fourth grade students.

With this research question in mind, the following experimental hypotheses were investigated:

Hypothesis 1: Both cross-age peer tutoring groups will have higher gain scores in writing than the students who received regular instruction only?

Hypothesis 2: Both cross-age peer tutoring groups will have higher gain scores in reading comprehension than the students who received regular instruction only.

Hypothesis 3: Both cross-age peer tutoring groups will have higher mean attitudes towards writing and writers' self-perception scores than the students who received regular instruction only.

ANOVAs with linear contrasts were used to determine whether there was a difference between the mean gain scores for at least two of the four treatment groups. The 
treatment groups were $3^{\text {rd }}$-grade tutoring group $(\mathrm{EC}), 3^{\text {rd }}$ grade non-tutoring group (CC), $4^{\text {th }}$-grade tutoring group (EC), and the $4^{\text {th }}$ grade non-tutoring group (CC).

Rather than compare each treatment group to every other treatment group, contrasts were used to answer each of the following three questions:

1. Do the gain scores differ for the $3^{\text {rd }}$ and $4^{\text {th }}$ grade?

2. Do the gain scores differ for tutoring and nontutoring?

3. Was there an interaction between tutoring and grade level?

In the tables that follow, these questions are answered in the order listed above. Writing Scores ( $\left.\mathrm{H}_{1}\right)$

Since Levene's statistic $=2.42(p=.07)$, there is some evidence that the variances of the writing gain scores are not equal. Hence, the contrasts for writing gain scores were tested under the assumption that the variances are not equal.

Since $t=-8.08 \quad(p<001)$ there is enough evidence to indicate that the mean writing gain scores differ for fourth grade students and third grade students. As seen in Table 4, the value of the contrast is -2.21 . We can 
conclude that the fourth grade students made more

improvement than the third grade students. It had been

hypothesized that the writing of students in the tutoring groups would improve more than that of the students in the non-tutoring groups. However, there was not enough evidence to support this claim. There is not enough evidence of an interaction between grade level and tutoring level (i.e., the effect of cross-age peer tutoring differs for third graders and fourth graders).

Table 4

Writing scores

\begin{tabular}{|c|c|c|c|c|c|}
\hline Contrasts & $\begin{array}{l}\text { Value of } \\
\text { Contrast }\end{array}$ & $\begin{array}{l}\text { Std. } \\
\text { Error }\end{array}$ & $t$ & $d f$ & $\mathrm{p}$ \\
\hline $\begin{array}{l}\text { WRITING IMPROVEMENT } \\
\text { 3rd grade versus } 4^{\text {th }} \text { grade } \\
\text { Non-tutoring versus tutoring } \\
\text { Interaction }\end{array}$ & $\begin{array}{r}-2.21 \\
-8.97 \\
-.43\end{array}$ & $\begin{array}{l}.27 \\
.27 \\
.27\end{array}$ & $\begin{array}{r}-8.08 \\
-.33 \\
-1.58\end{array}$ & $\begin{array}{l}111 \\
111 \\
111\end{array}$ & $\begin{array}{l}.00 \\
.74 \\
.12\end{array}$ \\
\hline
\end{tabular}

Reading Comprehension Scores $\left(\mathrm{H}_{2}\right)$

An ANOVA with linear contrasts was applied to gain scores for the Stanford Achievement Test reading comprehension subtest scores to see if there was a difference in the means for at least two of the four groups (see Table 5). There was not enough evidence to indicate that the mean gain scores for reading comprehension on the Stanford Achievement Test differed for third and fourth 
grade students. There was not enough evidence to indicate that the mean gain scores differed for the tutoring and non-tutoring groups. Since $t=-2.21(p=.03)$ there is sufficient evidence to indicate that grade level and peer tutoring interact to affect the mean gain scores for reading comprehension from the Stanford Achievement Tests. Table 5

Differences on the Stanford Achievement in Reading Comprehension Scores

\begin{tabular}{|c|c|c|c|c|c|}
\hline Contrasts & $\begin{array}{c}\text { Value of } \\
\text { Contrast }\end{array}$ & $\begin{array}{c}\text { Std. } \\
\text { Error }\end{array}$ & $t$ & df & $\mathrm{p}$ \\
\hline $\begin{array}{c}\text { Stanford Achievement Test - Reading } \\
3^{\text {rd }} \text { grade versus 4th grade }\end{array}$ & -3.08 & 4.61 & -.67 & 112 & .51 \\
non-tutoring versus tutoring & -4.59 & 4.61 & -.99 & 112 & .32 \\
interaction & -10.17 & 4.61 & -2.20 & 112 & .03 \\
Assumes equal variances & & & & & \\
\hline
\end{tabular}

Since the contrast's estimate is -10.17 , we can conclude that the third grade tutees did better compared to the other three groups in the study. In the non-tutoring group, fourth graders had higher mean scores, while in the tutoring group the third graders had higher mean scores. Although these means were not significantly different pairwise, the differences of these differences is significant. A possible explanation of this result may be that both 
fourth grade groups had the same teacher. The relationship between the means of the four groups is shown in Figure 1 .

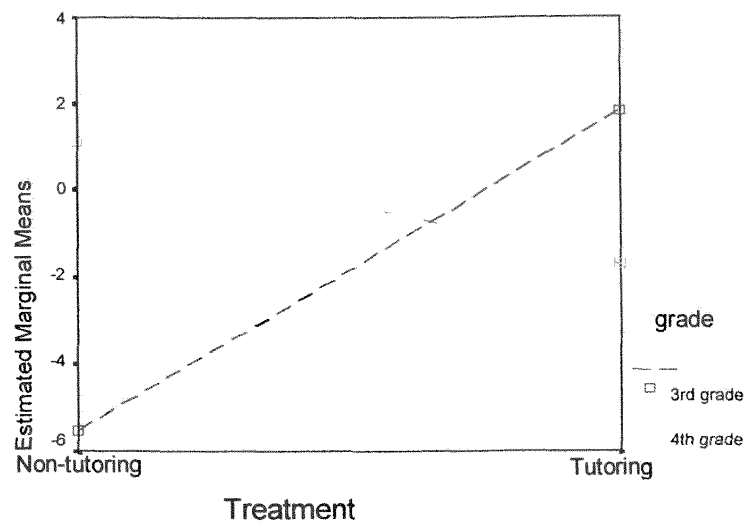

Eigure 1.

Plot of means for reading comprehension gain scores. Writer Self-Perception Scale Scores (H3)

ANOVAS with linear contrasts were done on each of the five sections of the Writer Self-Perception Scale (Bottomley, et al., 1997/1998) to determine if there were any significant differences in the mean scores of any of the groups. The same three questions answered for the writing gain scores and the reading comprehension subtest of the Stanford Achievement Test were answered for each of the sections of the Writer Self-Perception Scale (Bottomley, et al., 1997/1998).

For General Progress in writing (GP) scores Levine's statistic $=2.95(p=.04)$. Hence, there is evidence that the 
variance for the general progress in writing scores is not equal. Therefore, the contrasts for general progress in writing scores were tested under the assumption that the variances are not equal.

Since $t=-2.35(p=.02)$ there is enough evidence to indicate the mean General Progress in Writing scores (GP) differ for third grade and fourth grade students.

As seen in Table 6 , the contrast's estimate is -4.15 . Hence, the fourth grade students perceived that they made more general progress in writing than did the third grade students. There is not enough evidence to indicate that the means differ for the two levels of cross-age peer tutoring groups. There is not enough evidence of an interaction between grade level, participation in the crossage peer tutoring groups, and perception of general writing progress.

Table 6 General progress in Writing (GP)

\begin{tabular}{|c|c|c|c|c|c|}
\hline Contrasts & $\begin{array}{l}\text { Value of } \\
\text { Contrast }\end{array}$ & $\begin{array}{l}\text { Std. } \\
\text { Error }\end{array}$ & $t$ & $d f$ & $\mathrm{p}$ \\
\hline $\begin{array}{l}\text { GENERAL PROGRESS } \\
3^{\text {rd }} \text { grade versus } 4^{\text {th }} \text { grade } \\
\text { non-tutoring versus tutoring } \\
\text { interaction }\end{array}$ & $\begin{array}{r}-4.15 \\
-2.51 \\
1.59\end{array}$ & $\begin{array}{l}1.76 \\
1.76 \\
1.76\end{array}$ & $\begin{array}{r}-2.35 \\
-1.43 \\
.90\end{array}$ & $\begin{array}{l}95 \\
95 \\
95\end{array}$ & $\begin{array}{l}.02 \\
.16 \\
.37\end{array}$ \\
\hline
\end{tabular}


For Specific Progress in Writing (SP) scores $t=-2.65$

and $(p=.01)$ there was evidence to indicate the mean

Specific Progress in Writing scores (SPR) differ for third and fourth grade students. As seen in Table 7 , the contrast's estimate is -3.78 . Hence, the fourth grade students felt that they made more specific progress in writing than the third grade students. There was not enough evidence to indicate that the means differ for the two levels of cross-age peer tutoring groups. There was not enough evidence to indicate that grade level and crossage peer tutoring interact to affect perception of specific Progress in Writing (SPR) scores.

Table 7

Specific Progress in Writing (SPR)

\begin{tabular}{|c|c|c|c|c|c|}
\hline Contrasts & $\begin{array}{c}\text { Value of } \\
\text { Contrast }\end{array}$ & $\begin{array}{c}\text { Std. } \\
\text { Error }\end{array}$ & $t$ & $\mathrm{~d}$ \\
\hline SPECIEIC PROGRESS (SP) & -3.78 & 1.43 & -2.6 & 118 & .01 \\
$3^{\text {rd grade versus } 4^{\text {th }} \text { grade }}$ & -1.98 & 1.43 & -1.4 & 118 & .17 \\
non-tutoring versus tutoring & 2.01 & 1.43 & 1.4 & 118 & .16 \\
interaction & & & & &
\end{tabular}

For Observation Progress in Writing (OC) scores Levine's statistic $=2.64(p=.05)$ there is some evidence that the variances for observational progress in writing (OC) scores are not equal. Hence, the contrasts for 
observational progress in writing were tested under the assumption that the variances are not equal.

As seen in Table 8, there is not enough evidence to indicate that the mean Observational Progress in Writing (OC) scores differ for third and fourth grade students. There is not enough evidence that the means differ for the tutoring and non-tutoring groups. Since $t=2.00 \quad(p=.05)$ there is evidence of an interaction between grade level and participation in the cross-age peer tutoring groups on perception of Observational Progress in Writing (OC) scores.

Table 8

Observational Progress in Writing (OC)

\begin{tabular}{|c|c|c|c|c|c|}
\hline Contrasts & $\begin{array}{l}\text { Value of } \\
\text { Contrast }\end{array}$ & $\begin{array}{l}\text { Std. } \\
\text { Error }\end{array}$ & t & $d f$ & p \\
\hline $\begin{array}{l}\text { OBSERVATIONAL PROGRESS }(\mathrm{OC}) \\
3^{\text {rd }} \text { grade versus } 4^{\text {th }} \text { grade } \\
\text { non-tutoring versus tutoring } \\
\text { interaction } \\
\text { Does not assume equal variance }\end{array}$ & $\begin{array}{r}-1.14 \\
-.30 \\
4.56\end{array}$ & $\begin{array}{l}2.27 \\
2.27 \\
2.27\end{array}$ & $\begin{array}{r}-.50 \\
-.13 \\
2.00\end{array}$ & $\begin{array}{l}104 \\
104 \\
104\end{array}$ & $\begin{array}{l}.62 \\
.89 \\
.05\end{array}$ \\
\hline
\end{tabular}

Since the contrast's estimate is 4.56 , we can conclude that the third grade tutees did less well compared to the fourth grade tutors, than third grade non-tutoring compared to fourth grade non-tutoring. In the non-tutoring group, the fourth grade had lower mean scores, while in the 
tutoring group the fourth graders had higher mean scores. Although these means were not significantly different pairwise, the difference of these differences is significant. It is interesting to note that the tutors had a higher Observational. Progress in Writing (OC) score than the tutees. The relationship between the means of the four groups is shown in Eigure 2 .

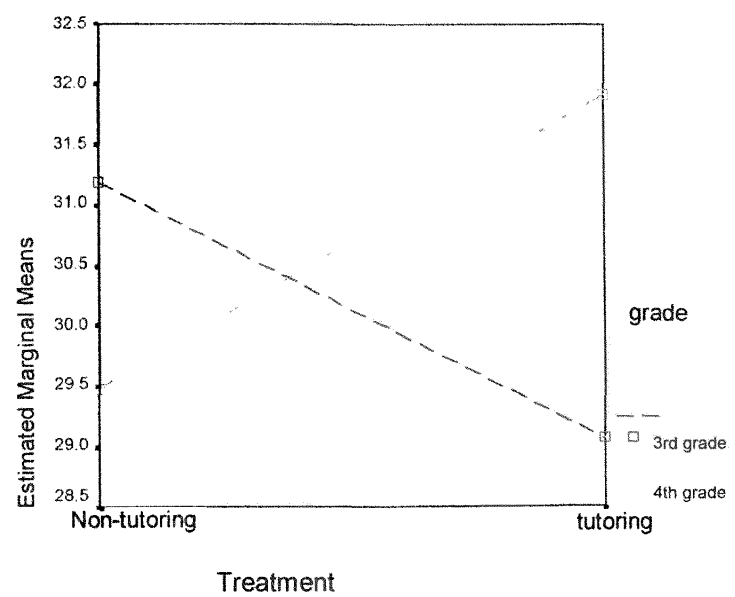

Eigure 2. Plot of means for Observational Progress in Writing $(O C)$

For Social Feedback in Writing (SE) scores $t=-2.14$ $(p=.03)$. The mean Social Eeedback (SE) in Writing scores differ for third and fourth grade students. As seen in Table 9 , the contrast's estimate is -3.22 , the fourth grade students perceived that they had more positive social feedback about their writing improvement than did the third 
grade students. There is not enough evidence that the means differ for the tutoring and non-tutoring groups. There is not enough evidence to indicate that grade level, and cross-age peer tutoring interact to affect social Feedback (SE) in Writing scores.

Table 9

Social Eeedback in Writing (SF)

\begin{tabular}{|c|c|c|c|c|c|}
\hline Contrasts & $\begin{array}{l}\text { Value of } \\
\text { Contrast }\end{array}$ & $\begin{array}{l}\text { Std. } \\
\text { Error }\end{array}$ & $t$ & df & $\mathrm{p}$ \\
\hline $\begin{array}{l}\text { SOCIAL EEEDBACK (SE) } \\
3^{\text {rd }} \text { grade versus } 4^{\text {th }} \text { grade } \\
\text { non-tutoring versus tutoring } \\
\text { interaction } \\
\text { Assume equal variances }\end{array}$ & $\begin{array}{r}-3.22 \\
-.36 \\
1.73\end{array}$ & $\begin{array}{l}1.50 \\
1.50 \\
1.50\end{array}$ & $\begin{array}{r}-2.14 \\
-.24 \\
1.15\end{array}$ & $\begin{array}{l}118 \\
118 \\
118\end{array}$ & $\begin{array}{l}.03 \\
.81 \\
.25\end{array}$ \\
\hline
\end{tabular}

Eor Psychological states while writing (PS) scores, Levene's statistic $=11.65(\mathrm{p}<.001)$ there is some evidence that the variances of the writing improvement scores are not equal. The contrast for Psychological states while writing (PS) scores was tested under the assumption that the variances are not equal.

The mean Physiological states (PS) in Writing scores did not differ for third and fourth grade students. Students in neither grade level thought that the act of writing made them feel better. There was not enough evidence that the means differ for the two levels of cross- 
age peer tutoring. Since $t=2.24(\mathrm{p}=.03)$, there is evidence that grade level and cross-age peer tutoring interact to affect Psychological states while Writing (PS) scores.

Table 10

Psychological states while writing (PS)

\begin{tabular}{|c|c|c|c|c|c|}
\hline Contrasts & $\begin{array}{l}\text { Value of } \\
\text { Contrast }\end{array}$ & $\begin{array}{l}\text { Std. } \\
\text { Error }\end{array}$ & $t$ & $d f$ & $\underline{p}$ \\
\hline $\begin{array}{r}\text { PSYCHOLOGICAL STATES } \\
3^{\text {rd }} \text { grade versus } 4^{\text {th }} \text { grade } \\
\text { non-tutoring versus tutoring } \\
\text { interaction }\end{array}$ & $\begin{array}{r}-1.19 \\
-3.21 \\
4.51\end{array}$ & $\begin{array}{l}2.01 \\
2.01 \\
2.01\end{array}$ & $\begin{array}{r}-.59 \\
-1.59 \\
2.24\end{array}$ & $\begin{array}{l}87 \\
87 \\
87\end{array}$ & $\begin{array}{l}.56 \\
.12 \\
.03\end{array}$ \\
\hline Does not assume equal variance & & & & & \\
\hline
\end{tabular}

Since the contrast's estimate is 4.51 , we can conclude that the third grade tutees did less well compared to the fourth grade tutors, and less well than the third grade non-tutoring did compared to the fourth grade non-tutoring. In the non-tutoring group fourth graders had lower mean scores, while in the tutoring group the fourth graders had higher mean scores. Although these means were not significantly different pair-wise, the difference of these differences is notable. It is interesting that those who tutored had higher Psychological states while writing (PS) scores than those who were tutored. The relationship between the means of the four groups is shown in Figure 3 . 


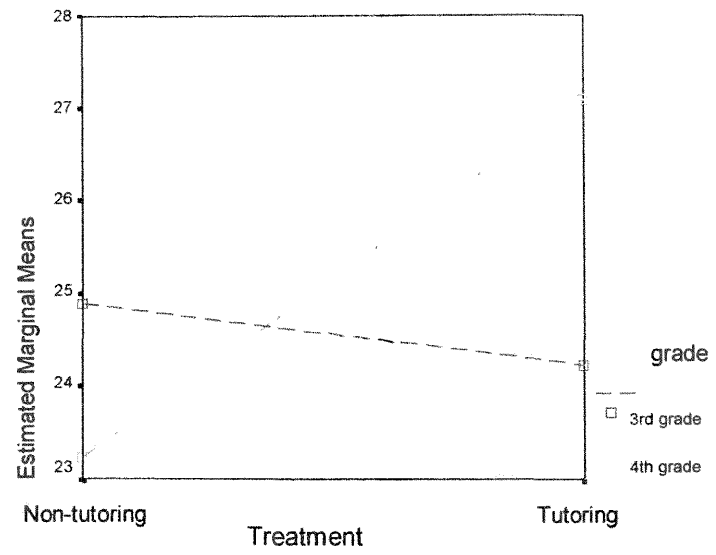

Figure 3. Plot of means of Psychological states While Writing (PS)

Furthermore, pair-wise analysis using the Games-Howell Procedure indicated that for fourth graders, those in the tutoring group felt that they were more relaxed and enjoyed writing more than the non-tutoring group. This seems to indicate that the fourth graders, who were peer tutors, came through the experience with a better attitude toward writing than the fourth graders who did not serve as peer tutors. For third graders, there were no differences in their perceptions.

When examining the gain scores for writing, there was not enough evidence that cross-age peer tutoring had an effect. This particular result was disappointing. Conversations with students indicated that the students had 
enjoyed working in the cross-age writing response groups and felt that they had benefited from the experience. Also, the researcher, while moving around the room observing the groups during the cross-age peer writing response sessions, observed more details, more adjectives and better word choices appearing in the students' writings. It was also apparent that the students were working on better beginnings and endings for their writings. Another indicator of progress was the tutors' reports on each session at the end of the one-hour period. These group self-reports also indicated an impression of progress being made by tutors and tutees.

Because of these observational indicators of progress, there was a need to reconsider and analyze the data. Crosstabulations were done on improvement level by treatment group, grade level, treatment, to determine if there were any significant differences in the proportions for at least two of the groups.

The rubric for scoring the writing samples on the Florida Writes! Test has a maximum score of six points in one-half point units $(0,1,1.5,2.0,2.5,3.0,3.5,4.0$, $4.5,5.0,5.5$, and 6). Also, the expected level of writing improvement after one semester of instruction is one point. 
Because of these facts, the improvement levels were defined as "expected or less" for statistical analysis if the student had a: negative change in scores from the pretest to the posttest; a change of .5; or a change of one point. "More than expected" was defined as: an improvement of more than one point on the posttest.

It had been hypothesized that there would be a relationship between level of improvement in writing and treatment group. There was not enough evidence to indicate that the proportions of those improving more than expected differ for the tutoring and the non-tutoring groups.

In comparing improvement level and treatment groups there is enough evidence to indicate that the proportions of those improving more than expected differ for at least two of the four groups. Pair-wise tests using the Holmes" Sequential Bonferroni Method for control of Type 1 Error were done to determine which pairs differ. Eor each pair of proportions Eisher's Exact Test was used because some of the expected values were less than 5. There are six pairs to compare, each comparison was done at the $(.05 / 6=.008)$ level. Table 11 shows the results of the pair-wise tests. 
Table 11

Eisher's Exact Test for Improvement Level and Treatment

Groups

\begin{tabular}{|c|c|c|}
\hline Groups & $\begin{array}{c}\text { Fisher's } \\
\text { Significant } \\
\text { Level } \\
\text { Fisher's Exact } \\
\text { Test }\end{array}$ & $\begin{array}{c}\text { Significant } \\
\text { Yes/No }\end{array}$ \\
\hline $3^{\text {rd }}$ Non-tutoring versus $4^{\text {th }}$ Tutoring & .00 & Yes \\
\hline $3^{\text {rd Non-tutoring versus } 4^{\text {th }} \text { Non-tutoring }}$ & .00 & Yes \\
\hline $3^{\text {rd }}$ Tutoring versus $4^{\text {th }}$ Non-tutoring & .00 & Yes \\
\hline $3^{\text {rd }}$ Tutoring versus $4^{\text {th }}$ Tutoring & .00 & No \\
\hline $3^{\text {rd }}$ Non-tutoring versus $3^{\text {rd }}$ Tutoring & .10 & No \\
\hline $4^{\text {th }}$ Non-tutoring versus $4^{\text {th }}$ Tutoring & .71 & \\
\hline
\end{tabular}

Table 12

Proportions Improving "more than expected"

\begin{tabular}{|c|c|}
\hline Treatment Group & $\begin{array}{c}\text { Improvement Level } \\
\text { "more than expected" }\end{array}$ \\
\hline $3^{\text {rd }} \begin{array}{r}\text { grade non-tutoring (CC) group } \\
\% \text { within treatment group }\end{array}$ & $26.9 \%$ \\
\hline $3^{\text {rd }} \begin{array}{r}\text { grade tutoring (EC) group } \\
\text { o within treatment group }\end{array}$ & $50.0 \%$ \\
\hline $4^{\text {th }} \begin{array}{r}\text { grade non-tutoring (CC) group } \\
8 \text { within treatment group }\end{array}$ & $90.3 \%$ \\
\hline $4^{\text {th }} \begin{array}{c}\text { grade tutoring (EC) group } \\
\text { within treatment group }\end{array}$ & $85.7 \%$ \\
\hline
\end{tabular}

Based on Table 12, and the results of the Fisher's

Exact Test (Table 11), it is clear that the fourth grade tutoring group had a higher proportion of "more than 
expected" than the third grade non-tutoring group. The fourth grade non-tutoring group had a higher proportion of "more than expected" than the third grade non-tutoring group. The fourth grade non-tutoring group had a higher proportion of "moxe than expected" than the third grade tutoring group. For the third grade non-tutoring versus the third grade tutoring, there was no effect. Eor the fourth grade non-tutoring group versus the fourth grade tutoring group, there was no effect. The fourth grade students in both the tutoring and non-tutoring groups had a higher proportion of "more than expected" scores than did the third grade tutoring and non-tutoring groups. There is the possibility of a teacher interaction, since the researcher was the language arts teacher for both fourth grade groups.

Summary

The main purpose of this study was to determine if cross-age peer tutoring had an impact on the writing and reading achievement, and the writers' attitudes toward writing and self-perceptions as writers for the third and fourth grade students involved in this study. Data were analyzed on the pretest and posttest scores for writing and reading and the students' responses on the Writer self- 
Perception Scale (Bottomley, et al., 1887/1998) of 122 third and fourth graders. ANOVAS with linear contrasts were applied to pretest and posttest scores of the Florida Writes! Test and the Stanford Achievement Test Reading Comprehension Sub-test scores for the 1996-1997 and the 1997-1998 school years and on the five sections of the Writer Self-Perception Scale (Bottomley, et al., $1887 / 1998)$.

- Mean writing gain scores differed for third and fourth grade students. The fourth grade students made more writing progress than the third grade students. Students in the tutoring groups did not improve significantly more than the students in the non-tutoring groups. There were no significant grade level and tutoring level interaction effects.

- Mean reading comprehension gain scores did not significantly differ for the third and fourth grade students. Mean reading comprehension gain scores were not significant for the tutoring and non-tutoring groups. There was evidence to suggest that grade level and peer tutoring interact to affect the mean reading comprehension scores. 
- The mean General Progress in Writing scores (GP) differed for the third and fourth grade students. Fourth grade students perceived that they made more progress than the third grade students. But there were no significant mean differences between the two levels of cross-age peer tutoring and no interaction between grade level, participation in the cross-age peer tutoring groups, and perception of general writing progress.

- The mean Specific Progress in Writing scores (SRR) differed for the third and fourth grade students. The fourth grade students felt they made more specific progress than the third grade students. There were no significant mean differences for the two levels of crossage peer tutoring groups, and no interaction for perception of specific writing progress.

- The means did not differ for the third and fourth students for the two levels of treatment in the area of Observational Progress (OC) in Writing. There were no significant mean differences for the two levels of crossage peer tutoring groups. There was significant interaction between grade level and participation in the cross-age peer tutoring groups and perception of observed writing progress. 
- The mean Social Eeedback (SE) scores did differ for third and fourth grade students. Fourth graders perceived that they had more positive social feedback than the third grade students. There were no significant mean differences for the two levels of treatment and no interaction for Social Feedback.

- The means did not differ for grade level or level of treatment for Physiological states in writing. Grade level and cross-age tutoring interacted to positively affect feelings experienced while writing. The fourth grade tutoring group came through the experiment with a better attitude toward writing than did the fourth grade students who did not serve as peer tutors. There were no differences in attitude towards writing for the third grade groups.

- There were no significant differences for "more than expected" in the tutoring and non-tutoring groups. The proportions of those improving did differ for grade level. More fourth graders improved "more than expected" than did third graders.

Eisher"s Exact Test was used in comparing improvement level and treatment groups, since there was enough evidence to indicate that the proportions of those improving "more 
than expected" differed for at least two of the four groups. Pair-wise tests were done on the six pairs to determine which pairs differed. The fourth grade students in both the tutoring and non-tutoring groups had a higher proportion of "more than expected" scores than did the third grade tutoring and non-tutoring groups.

In conclusion, while the tutoring groups did not make significantly more progress than the non-tutoring groups in writing and reading skills as measured on the posttests or on attitudes and self-perceptions as measured on the Writer Self-Perception Scale (Bottomley, et al., 1997/1998), there was evidence of growth in reading and writing, especially by the fourth graders. Most importantly, the fourth grade students, who served as peer tutors, had the most positive feelings about themselves as writers. Since the major purpose of this study was to examine whether participation in the cross-age peer tutoring writing response groups would have an effect on the improvement of writing skills and attitude towards writing, an improved attitude towards writing is an important student gain from participation in the treatment group. This positive change would seem to lead to more eventual growth in writing skills. 
CHAPTER FIVE

DISCUSSION

The purpose of this study was to determine experimentally the effectiveness of cross-age peer writing response groups on the writing and reading comprehension achievement of third and fourth grade students. Another purpose was to investigate the relationship between participation in the cross-age peer writing groups and the affective measure of students' attitudes towards writing and their perceptions of themselves as writers.

This chapter provides: (a) a summary of the design, procedures, and findings (b) discussion (c) reflections of a teacher-researcher, (d) recommendations for future research, and (f) final thoughts.

Summary of the Findings

It was clear from the study that the three research hypotheses were not supported. However, the following significant results were obtained.

1. The fourth grade students made great gain scores on writing than did the third grade students.

2. There was an interaction between tutoring status and grade level which affects reading comprehension gain scores. The third grade tutees (EC) had the highest 
gain scores in reading comprehension. Perhaps there was some aspect of being tutored that had an effect on their reading comprehension scores. There was very little difference in the fourth grade tutoring and non-tutoring groups. A possible explanation for this result may be that both fourth grade groups had the same language arts teacher, the author of this study.

3. Attitude toward writing and writer selfperceptions, as measured on the Writer selfPerception Scale (Bottomley, et al., 1997/1998) did improve for the fourth grade on the measures of General Progress in Writing (GP), Specific Progress in Writing (SP), and Social Eeedback (SE). The fourth grade tutoring and non-tutoring groups perceived that writing was easier than it used to be (General Progress in Writing). They also perceived that they had made more progress in the specific areas of better description, organization, and word choice (Specific Progress in Writing) than the third grade tutoring and non-tutoring groups. The fourth grade students also perceived that they got more positive Social Feedback (SE) on their 
writing from peers, family, and teachers than the third grade students.

4. There was an interaction between tutoring status and grade level, which affects Observational Progress in Writing (OC). The fourth grade tutors (EC) had the highest gain score. They perceived that when comparing their writing to others in the group, their writing was better. It is possible that the act of working with younger students and observing their writing skills had an effect on the fourth grade tutors' perceptions of their own writing.

5. There was an interaction between tutoring status and grade level, which affects Physiological states While writing (PS). The fourth grade tutors (EC) indicated that they were more relaxed and enjoyed writing more than the non-tutoring fourth grade group. There was no difference in the third grade tutoring and non-tutoring groups.

The three basic hypotheses, however, were not supported.

1. The results of this study did not support Hypothesis 1 that the students who participated in the cross- 
age peer writing response groups would achieve at a higher level on the Elorida Writes! Test than the students in the regular program. Writing achievement did not show significant improvement as a result of the cross-age writing response groups. 2. The results did not support Hypothesis 2 that the students who participated in the cross-age peer writing response groups would have higher gain scores on the reading comprehension subtest of the Stanford Achievement Test. Reading achievement did not show significant improvement as a result of the cross-age writing response groups.

3. The results did not support Hypothesis 3 that the students who participated in the cross-age peer writing response groups would have more positive attitudes toward writing and self-perceptions as writers scores as measured on the Writer selfPerception Scale (Bottomley, et al., 1997/1998). Discussion

The results of this study did not support Hypothesis 1 that the students who participated in the cross-age peer writing response groups would achieve at a higher level on 
the Florida Writes! Test than the students in the regular program.

However, there was evidence that the mean writing gain scores did differ by grade level. The fourth grade students made more improvement in writing than the third grade students. The fourth grade students had a higher proportion of "more than expected" than did the third grade students. This can be interpreted to mean that there were more fourth graders who had a gain of one or more points from the pretest to the posttest Florida Writes! Test score than there were third graders with this increase. Perhaps the fourth grade students were more motivated to improve their writing abilities because they knew they had to take the Florida Writes! Test. There is also the possibility of a teacher interaction. Both fourth grade groups had the same language arts teacher. There was no significance for the third grade non-tutoring group versus the third grade tutoring group and no significance for the fourth grade non-tutoring versus the fourth grade tutoring group.

The results did not support Hypothesis 2 that the students who participated in the cross-age peer writing response groups would have higher gain scores on the 
reading comprehension subtest of the Stanford Achievement Test.

While much of the current research emphasizes the reciprocal nature of reading and writing, that one helps in the constructing of meaning and information from the other, (Shanahan, 1984; Tierney \& Pearson, 1984; Goodman, 1986; Langer, 1986; Harste, Short, \& Burke, 1988; Routman, 1996), participation in the tutoring groups did not significantly affect reading achievement on the stanford Achievement Test. There was a grade level interaction. The third grade tutees (EC) had the highest gain score on the Stanford Achievement Test. Perhaps, the act of being tutored had some effect on their reading comprehension scores.

There were basically no differences in the mean gain scores for the fourth grade tutoring and non-tutoring groups. This result could have been due to the fact that the fourth grade students had to take the stanford Achievement Test and the ECAT Test and therefore, were more motivated than the third grade students. Perhaps, because the fourth graders were taking two reading comprehension tests with different formats, the extra ECAT Test preparation reinforced their reading skills. There is also 
the possibility of a teacher interaction. The author of this study was the language arts teacher for both fourth grade groups.

The results did not support Hypothesis 3 that students in the cross-age peer writing response groups would have higher scores in their attitudes toward writing and their perceptions of themselves as writers on the writer selfPerception Scale (Bottomley, et al., 1997/1998). However, the mean scores differed for third and fourth graders in three of the five sections. The fourth grade students perceived that they made more General Progress (GP) in writing than did the third grade students. The fourth grade students also felt that they made more Specific Progress (SP) than did the third grade students. The fourth grade students also felt that they received more positive social Eeedback (SF) about their writing than did the third grade students.

Eor Observational Progress in Writing scores (OC), there was evidence of an interaction between grade level and participation in the cross-age peer tutoring groups. Pair-wise analysis of the treatment means was done to determine the nature of the interaction. However, none of the pairs of means was determined to be different. The 
third grade tutees (EC) had the lowest mean score of any of the three groups. Perhaps the participation in the writing groups had made them aware for the first time of how much there is to learn about writing well. The third grade nontutoring group had a higher mean score than the third grade tutees (EC) and the fourth grade non-tutoring group (CC). This might be that they have not yet had the experience in writing instruction or the amount of feedback from peers that the other groups had experienced. Therefore, they were not able to make a realistic evaluation of their writing compared to the writing of others. The fourth grade tutors (EC) had the highest mean score. Perhaps the experience of tutoring younger students empowered them as they compared their own skills to the students they were tutoring.

The mean Physiological states (PS) in Writing scores did not differ for third and fourth graders. There was not enough evidence that students in either grade level thought that the act of writing made them feel better. There was evidence of an interaction between grade level and crossage peer tutoring to affect feelings experienced while writing. The fourth grade students in the tutoring group indicated that they were more relaxed and enjoyed writing 
more than the fourth grade non-tutoring group. Again, this could be a result of working with younger students and comparing their writing to the students they were tutoring. Pearson (1991) found after reviewing the comprehension research of the 1980s, that when students have to transform ideas from one form to another they understand and remember ideas better. Perhaps, this transforming of ideas about writing skills for their tutoring groups influenced the tutors' positive feelings and perceptions about their knowledge of writing skills.

Reflections of a Teacher-Researcher

While it was disappointing that the treatment did not appear to have a significant effect on writing improvement, there were qualitative indicators of progress. The researcher observed the treatment groups as they participated in all of the cross-age peer response sessions. The students were actively involved in the writing discussions and the writing being shared seemed to be showing improvement in the form of: (a) better beginnings and endings, (b) better idea development, and(c) better word choices. Also, the informal interviews with the students indicated that the students enjoyed working in 
the groups and felt that they had benefited from the experience.

Graves (1994) emphasizes that it is extremely important to teach children to read their own writing if there is to be any improvement. This learning of skills to share one's own writing, and to read for the purpose of strengthening the writing, shifts the responsibility for writing improvement from the teacher to the children. The researcher observed the children taking the control that Graves described during this study. While the results did not reach the level of statistical significance, the children did show maturity in their thinking about their own writing and the writing of the others in their response group.

It is important to remember that the fourth grade tutors had the most positive attitudes toward writing and the best perceptions of themselves as writers when compared to the other three treatment groups. Perhaps the experience of tutoring younger students in the writing process can build self-confidence in tutors and increase their motivation to write. At least with this particular sample of students, this did seem to be the case. 
The fact that the tutors in the study had a higher gain score for attitude toward writing and self-perception as writers is important. With the emphasis on writing in the curriculum today, it is important that students have a positive attitude toward writing. According to Bandura's (1977, 1982) theory of perceived self-efficacy, a child's self-perception of writing ability will affect his/her subsequent writing growth. Bandura predicts that individuals who have positive writer self-perceptions will probably pursue opportunities to write, expend more effort during writing, and demonstrate greater persistence in seeking writing competence.

As adults, people rarely work in complete isolation. Working in these cross-age peer tutoring groups requires that students learn how to cooperate, display encouraging behaviors, learn to share together, and how to provide support for each other (Goatley, 1996). These are all important life skills to be learned. To be learned they must be practiced in a group setting.

Teachers should encourage students to write with a certain audience in mind to give students a real sense of purpose in their writing (Graves, 1994). The students in this elementary school were involved in a fifteen-minute 
sustained independent writing activity daily with a prompt supplied by the principal at the end of the morning announcements. This activity was not always successful. Many teachers reported that the students were often bored and dreaded the required daily assignment. There was some evidence that the two tutoring groups (EC) (third grade tutees and fourth grade tutors) were more enthusiastic about this daily assignment because they were writing these writes to be shared in the weekly tutoring group.

More gains may have been evident in this study if all four of the classes had not been limited to high stanines and gifted students. The ceiling effect of having students who were already considered above average may perhaps have Iimited student gains. There was not as much room for growth in these classes as might have been seen in homogeneous groups.

Recommendations for Future Research

Based on the findings in this study the following recommendations for future research are being made:

1. Replicate the study to determine if cross-age peer writing response groups improve reading and writing achievement under the following conditions: 
a. Lengthen the timeline of the study to give the tutors and the tutees more time to learn and use the sharing techniques used in the study.

b. Increase the amount of time of the tutoring sessions to longer than one hour a week, or meet for two one-hour sessions a week.

c. Use the Writer Self-Perception Scale (Bottomley, et al., 1997/1998) as a pretest and a posttest measurement to be able to measure the growth of attitudes and self-perceptions about writing.

d. Collect qualitative data during the study, including interviews with the students on how they think through deciding what they need to do to improve their writing.

e. Conduct the study using other age appropriate writing techniques instead of Peter Elbow's "movies in my mind," "pointing," and "summarizing" (1978, 1998).

f. Conduct the study using a more heterogeneous group of children to avoid the possible ceiling effect of having a group of high achieving students who start the intervention with higher scores, thereby having less room to make improvements. 
2. Examine the effects of reciprocated roles within the response groups. In other words, have the students exchange the roles of tutor and tutee every other week.

3. Examine the effects of using the writing response groups using students in the same grade level instead of crossage groups.

4. Examine the effects of using the writing response groups in the content areas on the reading comprehension and writing achievement of students.

5. Investigate how direct instruction of other selected writing strategies followed up in cross-age peer writing response groups affects writing and reading comprehension achievement, attitudes about the act of writing, and the students' perceptions of themselves as writers.

6. Increase the sample size to increase statistical power and make the results more generalizable to the population. With an increase in sample size, other variables such as gender and ethnicity could be examined.

\section{Einal Thoughts}

Recent changing theoretical perspectives and definitions of literacy have emphasized the fact that learners should be actively engaged in constructing meaning as they read, write, and discuss texts. Learners should be 
actively engaged in meaningful literacy activities that provide opportunities for others more knowledgeable to advance their literacy abilities (McMahon \& Raphael, 1997; Vygotsky; 1978, Graves, 1994). Even though this study did not find significance for the writing and reading comprehension achievement that had been hoped for, many positive things were cited in this study. The evidence indicates that the fourth grade (EC) tutors experienced the most positive growth in their attitude toward writing and their perceptions of themselves as writers.

All of the third grade gifted students, who had participated in the study as the third grade (EC) tutees, were placed in the researcher's fourth grade classroom for the next academic school year. As a group, they requested that, as fourth grade students, they be allowed to do the experiment again so that they could participate as the tutors. This positive response from the original tutees seems to indicate that, while their progress did not show significance in this study, they had been positively impacted by the encouragement and help they had received and the skills they had learned during the experience of cross-age peer writing response groups. 
Allen, V. L. (1976). Children as teachers: Theory and research on tutoring. New York: Academic Press.

Anderson, R. C., Hiebert, E. H., Scott, J. A., \& Wilkinson, I. A. G. (1985). Becoming a nation of readers. Washington, DC: National Institute of Education, National Acaderny of Education, Commission on Reading.

Atwell, N. (1987). In the middle: Writing, reading, with adolescents. Portsmouth, NH: Heinemann.

Austin, P. J. (1987). The effects of instruction and teacher feedback on revision of writing tasks by fourth grade students within the naturalistic context of the classroom. Dissertation Abstracts International. Vol. 4903A.

Bandura, A. (1977). Self-efficacy: Toward a unifying theory of behavioral change. Psychological Review, 84, 191215 .

Bandura, A. (1982). Self-efficacy mechanism and human agency. American Psychologist, 37, 122-147.

Bereiter, C., \& Scardamalia, M. (1982). From conversation to composition: The role of instruction in a developmental process. In R. Glaser (Ed.), Advances in instructional psychology, Vol. 2, 1-64. Hilisdale, NJ: Erlbaum.

Berliner, D., \& Casanova, U. (1986). How to make cross-age tutoring work. Instructor, 95(9), 14-15.

Bottomley, D. M., Henk, W. A., \& Melnick, S. A. (1997/1998). Assessing children's views about themselves as writers using the Writer Self-Perception Scale. The Reading Teacher, 51, 286-296.

Boyle, O. F., \& Peregoy, S. F. (1990). Literacy scaffolds: Strategies for first-and-second-language readers and writers. The Reading Teacher, 44, 194-200. 
Braddock, R., Lloyd-Jones, R., \& Schoer, L. (1963). Research in written composition. Urbana, IL: National Council of Teachers of English.

Bridge, C. A., \& Hiebert, E. H. (1985). A comparison of classroom writing practices, teachers' perceptions of their writing instruction, and textbook recommendations on writing practices. Elementary School Journal, 86, 155-172.

Britton, J. (1970). Language and learning. Portsmouth, $\mathrm{NH}$ : Heinemann/Boynton.

Britton, J. (1972). The present state of theory and knowledge relating to English. Teaching English in Australia, 22, 9-24.

Britton, J., Burges, T., Martin, N., Mcleod, A., \& Rosen, H. (1975). The development of writing abilities, 1118. London: Macmilian.

Bruner, J. (1985). Models of the learner. Educational Researcher, 14, 6, 5-8.

Bureau of Educational Information and Assessment Services (1994). Elorida writes! Report on the 1994 Assessment. Tallahassee, Florida: State Department of Education.

Burrows, A. T. (1955). Composition: Erospect and retrospect. In H. A. Robinson (Ed.), Reading and writing instruction in the united States: Historical trends (pp.331). Urbana, IL: ERIC and International Reading Association.

Butterworth, G. (1993). Context and cognition in models of cognitive growth. In P. Light \& G. Butterworth (Eds.), Context and cognition: Ways of learning and knowing (pp. 1-13). Hilisdale, NJ: Erlbaum.

Calkins, L. M. (1983). Lessons from a child: On the teaching and learning of writing. Exeter, NH: Heinemann.

Calkins, L. M. (1986). The art of teaching writing. Portsmouth, NH: Heinemann. 
Calkins, I. M. (1991). Living between the lines. Portsmouth, $\mathrm{NH}$ : Heinemann.

Calkins, L. M. (1994). The art of teaching writing: New edition. Portsmouth, $\mathrm{NH}$ : Heinemann.

Campbe11, D. T., \& Stanley, J. C. (1963). Experimental and quasi-experimental designs for research. Chicago, IL: Rand McNally.

Cramer, E. \& Castle, M. (Eds.). (1994). Fostering the love of reading: The affective domain in reading education. Newark, DE: International Reading Association.

Clay, M. M. (1991). Child development. In J. Flood, J. M. Jensen, D. Lapp, J. R. Squire (Eds.), Handbook of research on teaching the English language arts (pp.40-45). New York: Macmillan Publishing Company.

Cha11, J. S., Conrad, S., \& Harris, S. (1977). An analysis of textbooks in relation to falling SAT scores. New York: College Entrance Examination Board.

Cohen, P. A., Kulik, J. A., \& Kulik, C. C. (1982). Educational outcomes of tutoring: A meta-analysis of findings. American Educational Research Journal 19, 2, 237 248 .

Cole, M. (1996). Cultural psychology: A once and future discipline. Cambridge, MA: Belknap Press of Harvard University Press.

Committee on the National Interest. (1961). The national interest and the teaching of English: A report on the status of the profession. Urbana, IL: National Council of Teachers of English.

Committee on the National Interest (1964). The national interest and the continuing education of teachers: A report on the status of the profession of English. Urbana, IL: National Council of Teachers of English.

Cook, T., and CampbelI, D. (1979). QuasiExperimentation: Design and analysis issues for field settings. Chicago: Rand McNally. 
Dahl, K.L., \& Earnan, N. (1998). Children's writing: Perspectives from research. Newark, DL: International Reading Association.

Damon, W., \& Phelps E. (1989a). Three approaches of peer learning and their educational uses. Paper presented at the annual meeting of the American Educational Research Association, New Orleans, LA, (1988, April).

Damon, W., \& Phelps, E. (1989b). Strategic uses of peer learning in children's education. In T. J. Berndt \& G. W. Ladd (Eds.), Peer relationships in child development (pp. 49-56). New York: John Wiley and Sons.

Doyle, W. (1990). Themes in teacher education. In $W$. R. Houston (Ed.), Handbook of research on teacher education. (pp. 38-53). New York: Macmillan.

Early, M. (1991). Major research programs. In Flood, J., Jensen, J. M., Lapp, D., and Squire, J. R. (Eds.), Handbook of research on teaching the English language arts (pp. 143-158). New York: Macmilian.

Elbow, P. (1973). Writing without teachers. New York: oxford University Press.

Elbow, P. (1998). Writing without teachers: Second edition. New York: Oxford University Press.

Emig, J. (1971). The composing processes of twelfth graders. (Research Report No. 13). Urbana, IL: National Council of the Teachers of English.

Evans, K. S. (1997). Exploring the complexities of peer-led literature discussions: The influence of gender. In J. R. Paratore \& R. L. McCormack (Eds.), Peer talk in the classroom: Learning from research. Newark, Delaware: International Reading Association.

Eaigley, L. (1986). Competing theories of process. College English, 48, 527-542.

Elower, L., \& Hayes, J. (1980). The dynamics of composing: Making plans and juggling constraints. In L. Gregg \& E. Steinberg (Eds.), Cognitive processes in writing (pp.31-50). Hillsdale, NJ: Erlbaum. 
Elower, L., Hayes, J. R., Corey, L., Schriever, K., \& Stratman, J. (1986). Detection, diagnosis, and the strategies of revision. College composition and Communication, $37,16-55$.

Eranklin, A. E. (1992). Learning to read and write the natural way. Teaching Exceptional Children, 24, 45-48.

Friend, M., \& Bursuck, W. (1996). Including students with special needs: A practical guide for classroom teachers. Boston: Allyn \& Bacon.

Gardner, H. (1991). The unschooled mind: How children think \& how schools should teach. New York: Basic Books.

Gaustad J. (1993). Peer and cross-age tutoring. ERIC Digest 79. Eugene, OR: ERIC Clearinghouse on Educational Management.

Gay, L. R. (1996). Educational research: Competencies for analysis and application. Upper saddle River, NJ: Merrill.

Gentile, C. A. (1992). Exploring new methods for collection students' school-based writing. National Center for Educational Statistics. Washington, DC: U. S. Government Printing Office.

Goatley, V. J. (1997). Talk about text among special education students. In S. I. McMahon \& T. E. Raphael (Eds.), with V. J. Goatley \& L. S Pardo. The book club connection: Literacy learning and classroom talk (pp. 119137). New York: International Reading Association.

Goodman, K. (1967). Reading: A psychololinguistic guessing game. Journal of the Reading Specialist, 6, 126135.

Goodman, K. (1986). What's whole in whole language? Portsmouth, NH: Heinemann.

Goodman, K., \& Goodman, Y. (1977). Learning about psycholinguistic processes by analyzing oral reading. Harvard Educational Review, 47, 317-333. 
Goodman, K., \& Goodman, Y. (1983). Reading and writing relationships: Pragmatic functions. Language Arts, 60, 590599.

Graves, D. H. (1978). Balance the basics: Let them write. New York: Ford Eoundation.

Graves, D. H. (1981). Break the welfare cycle: Let writers choose their topics. In D. H. Graves (Ed), A case study observing the development of primary children's composing, spelling, and motor behaviors during the writing process (Einal report, 388-394. NIE Grant No. G78-0174). Durham, NH: University of New Hampshire.

Graves, D. H. (1983a). Writing: Teachers and children at work. Exeter, NH: Heinemann.

Graves, D. H. (1983b). A new look at writing research. In D. H. Graves, A researcher learns to write. Portsmouth, NH: Heinemann.

Graves, D. H. (1984). A researcher learns to write. (Balance the basics: Let them write). Portsmouth, NH: Heinemann.

Graves, D. H. (1991). All children can wright. In S. Stires (Ed.), With promise. Portsmouth, NH: Heinemann.

Graves, D.H. (1994). A fresh look at writing. Portsmouth, NH: Heinemann.

Gray, J., \& Myers, M. (1978). Bay Area Writing Project. Phi Delta Kappan, 59, 410-413.

Greenwood, C. R., Delquardi, J. C., \& Hall, R. V. (1989). Longitudinal effects of classwide peer tutoring. Journal of Educational Psychology, 81/3, 371-383.

Guanarsson, B. I. (1997). The writing process from a sociolinguistic viewpoint. Written Communication, 14, 139188.

Halliday, M. A. K. (1975). Learning how to mean. London, UK: Arnold. 
Halliday, M. A. K. (1978). Language as social semiotic. London, UK: Arnold.

Haliday, M. A. K. (1984). Three aspects of children"s language development: Learning language, learning through language, and learning about language. In Y. Goodman, M. Haussler, \& D. Strickland (Eds.), Oral and written language development research: Impact on the schools (pp. 165-192). Urbana, IL: National Council of Teachers of English.

Harper, L. (1997). The writer's toolbox: Five tools for active revision instruction. Language Arts, Vol.74. $193-200$.

Harste, J. C., Woodward, V. A., \& Burke, C. I. (1984). Ianguage stories and literacy lessons. Portsmouth, NH: Heinemann.

Harste, J. C., Short, K. G., \& Burke C. (1988). Creating classrooms for authors: The reading-writing connection. Portsmouth, NH: Heinemann.

Hoskisson, K., \& Tompkins, G. E. (1987). Language arts: Content and teaching strategies. Columbus, $\mathrm{OH}$ : Merrill.

House, J. D. (1988, November). An investigation of the effect of student and tutor gender on grades earned in college mathematics and science courses. Paper presented at the annual meeting of the Illinois Association for Institutional Research, Rosemont, IL. (ERIC Document Reproduction Service No, ED 301480 ).

Johnson, D. W., \& Johnson R. T. (1975). The use of cooperative, competitive, and individualistic goal structures within the classroom. Englewood Cliffs, NJ: Prentice-Hall.

Kinneavy, J. I. (1987). Writing across the curriculum. In G. Tate (Ed.), Teaching composition: 12 bibliographic essays (revised edition). (pp. 353-377). Eort Worth, Texas: Christian University Press. 
Lickteig, J., Johnson B., \& Johnson, D. (1994, Spring). Future teachers' reflections, perceptions, and anticipations about reading and writing. Journal of Reading Education, 19, 22-43.

Levin H. M., Glass, G. V., \& Meister, G. R. (1987). Cost-effectiveness of computer-assisted Instruction. Evaluation Review, 11-1, 50-72.

McCarthy, S. J., \& Raphael, T. E. (1992). Alternative research perspectives. In Irwin \& Doyle (Eds.), Reading/writing connections: Learning from research (pp. 231). Newark: DL International Reading Association.

McCutchen, D., \& Perfetti, C. A. (1983). Local coherence: Helping young writers manage a complete task. Elementary School Journal, 84, 71-75.

McMahon, S. I., \& Raphael, T. E. (1997). In S. I. McMahon \& T. E. Raphael (Eds.), with V. J. Goatley \& L. S. Pardo. The book club connection: Literacy learning and classroom talk (pp. 3-25). New York: International Reading Association.

Murray, D. M. (1984). Facets: The most important developments in the last five years for high school teachers of composition. English Journal, 78, 21.

Murray, D. M. (1987). Internal revision: A process of discovery. In C. R. Cooper \& L. Odell (EdS.), Research on composing: Points of departure (pp. 85-103). Urbana, IL: National Council of Teachers of English.

National Assessment of Educational Progress (1981). Reading, thinking, and writing: Results from the 1979-1980 national assessment of reading and literature. Denver, $\mathrm{CO}$ : Education Commission of the United States.

National Commission on Excellence in Education (1983). A nation at risk. Washington D. C.: U.S. Department of Education.

Nystrand, M. (1989). A social-interactive model of writing. Written Communication, 6, 66-85. 
Palinscar, A. S. (1984). The quest for the meaning from expository text: A teacher-guided journey. In G. Duffy, L. Roechler, \& J. Mason (Eds.), Comprehensive instruction: Perspectives and suggestions (pp. 251-264). White Plains, NY: Longman.

Palinscar, A. S., \& Brown A. I. (1986). Interactive teaching to promote independent learning from test. The Reading Teacher, 39, 8, 771-777.

Pearson, P. D., \& Fielding, L., (1991). Comprehension Instruction. In R. Barr, M. Kamil, P. Mosenthal, and P. D. Pearson (Eds.), Handbook of Reading Research Volume II. (pp. 815-860).

Pigott, H. E., Eantuzzo, J. W., \& Clement P. W. (1986). The effects of reciprocal peer tutoring and group contingencies on the academic performance of elementary school children. Journal of Applied Behavior Analysis, 19, $1,93-98$.

Pilen, B. L., Jason, L. A., \& Olson, T. (1988). The effects of gender on the transition of transfer students into a new school. Psychology in the schools, 25, 187-194.

Rief, L. (1992). Seeking diversity. Portsmouth, NH: Heinemann.

Rekrut, M. D. (1992, April). Teaching to learn: Cross-age tutoring to enhance strategy acquisition. Paper presented at the annual meeting of the American Educational Research Association, San Erancisco, CA. (ERIC Document Reproduction Service No. 348 363).

Rekrut, M. D. (1994). Peer and cross-age tutoring: The lessons of research. Journal of Reading, 37, 5, 356-362.

Reutzel, D. R., \& Cooter, R. B. (1999). Balanced Reading strategies and practices: Assessing and assisting readers with special needs. Upper Saddle River, NJ: Merrill.

Rogoff, B. (1986). Adult assistance of children's learning. In T. E. Raphael (Ed.), Contexts of school-based literacy (pp. 27-40). New York NY: Random House. 
Routman, R. (1994). Invitations: Changing as teachers and learners $\mathrm{K}-12$. Portsmouth, NH: Heinemann.

Routman, R. (1996). Literacy at the crossroads: critical talk about reading, writing, and other teaching dilemmas. Portsmouth, NH: Heinemann.

Scardamalia, M., \& Bereiter C. (1986). Research on written composition. In W. C. Wittrock (Ed.), Handbook of research on teaching, (pp. 778-803). New York: Macmilian.

Schunk, D. H. (1984). Self-efficacy perspective on achievement behavior. Educational Psychologist, 19, 48-58.

Shanahan, T. (1984). The nature of the reading and writing relation: An explanatory multivariate analysis. Journal of Educational Psychology, 76, 466-477.

Shanahan T., \& Lomax, R. (1986). An analysis and comparison of theoretical models of the reading-writing relationship. Journal of Educational Psychology, 78, 466477.

Slavin, R. E. (1980). Cooperative learning. Review of Educational Research, 50, 315-342.

Smith, E. (1983). Reading like a writer. Language Arts, 60, 558-567.

Sommers, N. (1980). Revision strategies of student writers and experienced writer. College composition and Communication, $31,378-388$.

Squire, J. R. (1991). The history of the profession. In Flood, J., Jensen, J. M., Lapp, D., and Squire, J. R. (Eds.), Handbook of research on teaching the English language arts (pp. 3-17). New York: Macmillan.

Stevens, R. J., Madden, N. A., Slavin, R. E., \& Earnish, A. M. (1987). Cooperative integrated reading and comprehension: Two field experiments. Reading Research Quarterly, XXII, 433-453.

Stotsky, S. (1983). Research on reading/writing relationships: A synthesis and suggested directions. Language Axts, 60, 5, 627-642. 
Swenge1, E. M. (1991). Cutting education's gordian knot. Phi Delta Kappan, 72, 5, 704-710.

Tierney, R. J., \& Pearson, P. D. (1984). Toward a composing model of reading. In J. Jensen (Ed.), Composing and comprehending (pp.33-46). Urbana, IL: National Conference on Research in English.

Topping, K., \& Whiteley, M. (1993). Sex differences in the effectiveness of peer tutoring. School Psychology International, 14, 1, 57-67.

Turner, J., \& Paris, S. (1995). How Iiteracy tasks influence children's motivation for literacy. The Reading Teacher, 43, 662-673.

Tway, E. (1984). Time for writing in the elementary school. Urbana, IL: National Council of Teachers of English and ERIC Clearinghouse on Reading and Communication Skills.

Tway, E. (1985). Writing is reading: 26 ways to connect. Urbana, IL: National Council of Teachers of English and ERIC Clearinghouse on Reading and Communication Skills.

Vygotsky, L. S. (1962). Thought and language. Cambridge, MA: Massachusetts Institute of Technology Press.

Vygotsky, L. S. (1978). Mind in society: The development of higher psychological processes (edited by $M$. Cole, V. John-Steiner, S.Scribner \& E. Souberman). Cambridge, MA: Harvard University Press.

Vygotsky, L. S. (1986). Thought and language. Cambridge MA: Harvard University Press.

Werstch J. V. (1985). Vygotsky and the social formation of mind. Cambridge MA: Harvard University Press. 
APPENDICES 
Appendix A - Experimental Writing Response Groups 


\section{Appendix A}

Experimental Writing Response Groups

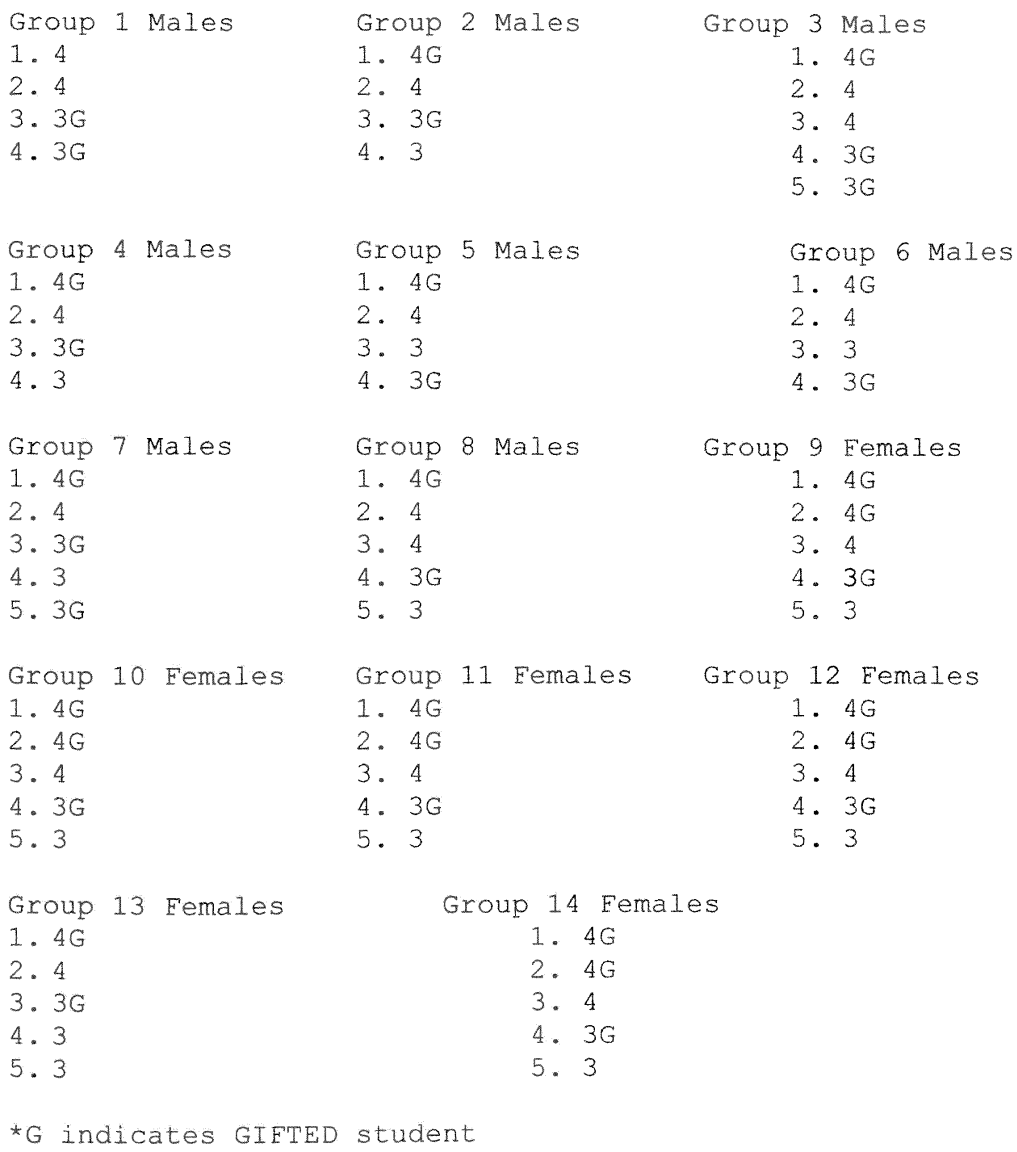


Appendix B - Writer Self-Perception Scale 


\section{APPENDIX A \\ The Writer Self-Perception Scale}

Listed below are statements about writing. Please read each statement carefully. Then circle the letters that show how much you agree or disagree with the statement. Use the following scale:

$$
\begin{aligned}
S A & =\text { Strongly Agree } \\
A & =\text { Agree } \\
U & =\text { Undecided } \\
D & =\text { Disagree } \\
S D & =\text { Strongly Disagree }
\end{aligned}
$$

Example: I think Batman is the greatest super hero.

SA A U D SD

If you are really positive that Batman is the greatest, circle SA (Strongly Agree).

If you think that Batman is good but maybe not great, circle A (Agrce).

If you can't decide whether or nor Batman is the greatest, circle U (Undecided).

If you think that Batman is not all that great, circle D (Disagree).

If you are really positive that Batman is not the greatest, circle SD (Strongly Disagree).

(OC) 1. I write better than other kids in my class.

(PS) 2.I like how writing makes me feel inside.

(GPR) 3. Writing is easier for me than it used to be.

(OC) 4. When I write, my organization is better than the other kids in my class.

(SF) 5. People in my family think I am a good writer.

(GPR) 6.I am getting better at writing.

(PS) 7. When I write, I feel calm.

(OC) 8. My writing is more interesting than my classmates' writing.

(SF) 9. My teacher thinks my writing is fine.

(SF) 10. Other kids think I am a good writer.

(OC) 11. My sentences and paragraphs fit together as well as my classmates' sentences and paragraphs.

(GPR) 12. I need less help to write well than I used to.

(SF) 13. People in my family think I write pretty well.

(GPR) 14. I write better now than I could before.

(GEN) 15. I think I am a goos writer.

(OC) 16.I put my sentences in a better order than the other kids.

(GPR) 17. My writing has improved.

(GPR) 18. My writing is better than before.

(GPR) 19. It's easier to write well now than it used to be.

(GPR) 20. The organization of my writing has really improved.

(OC) 21. The sentences I use in my writing stick to the topic more than the ones the other kids use.

(SPR) 22. The words I use in my writing are better than the ones I used before.

(OC) 23.1 wrile more often lian other kids.
SA A U D $\quad$ SD

SA A U D SD

SA. A U D $\quad$ SD

SA A U D $\quad$ SD

SA $\quad A \quad U \quad D \quad S D$

SA A U D $\quad$ SD

SA A U D SD

SA A U D $\quad$ SD

SA $\quad A \quad U \quad D \quad S D$

SA A U D $\quad$ SD

SA A U D SD

SA A U D SD

SA A U D SD

$S A \quad A \quad U \quad D \quad S D$

SA A U $\quad$ D $\quad$ SD

SA A U D SD

SA A U D SD

$S A$ A U D SD

SA A U D SD

$S A$ A U D SD

SA A U D SD

SA A U D SD

SA A U D SD 


\section{APPENOTX A (cont'd.) \\ The Writer Selt.Perception Scale}

(PS) 24. I am relaxed when I write.

(SPR) 25. My descriptions are more interesting than before.

(OC) 26. The words I use in my writing are better than the ones other kids use.

(PS) 27. I feel comfortable when I write.

(SF) 28. My teacher thinks I am a good writer.

(SPR) 29. My sentences stick to the topic better now.

(OC) 30 . My writing seems to be more clear than my classmates' writing.

(SPR) 31. When I write, the sentences and paragraphs fit together better than they used to.

(PS) 32. Writing makes me feel good.

(SF) 33. I can tell that my teacher thinks my writing is fine.

(SPR) 34. The order of my sentences makes better sense now.

(PS)

(SPR) 36. My writing is more clear than it used to be.

(SF) 37. My classmates would say I write well.

(SPR) 38. I choose the words ! use in my writing more carefully now.

\begin{tabular}{|c|c|c|c|c|}
\hline $\begin{array}{l}\text { SA } \\
\text { SA }\end{array}$ & $\begin{array}{l}\mathbf{A} \\
\mathbf{A}\end{array}$ & $\begin{array}{l}U \\
U\end{array}$ & $\begin{array}{l}D \\
D\end{array}$ & $\begin{array}{l}S D \\
S D\end{array}$ \\
\hline SA & A & $U$ & D & SD \\
\hline $\begin{array}{l}\text { SA } \\
\text { SA } \\
\text { SA } \\
\text { SA }\end{array}$ & $\begin{array}{l}\mathbf{A} \\
\mathbf{A} \\
\mathbf{A} \\
\mathbf{A}\end{array}$ & $\begin{array}{l}U \\
U \\
U \\
U\end{array}$ & $\begin{array}{l}D \\
D \\
D \\
D\end{array}$ & $\begin{array}{l}S D \\
S D \\
S D \\
S D\end{array}$ \\
\hline SA & $\mathbf{A}$ & $U$ & D & \\
\hline $\begin{array}{l}\text { SA } \\
\text { SA } \\
\text { SA } \\
\text { SA } \\
\text { SA } \\
\text { SA }\end{array}$ & $\begin{array}{l}\mathbf{A} \\
\mathbf{A} \\
\mathbf{A} \\
\mathbf{A} \\
\mathbf{A} \\
\mathbf{A} \\
\mathbf{A}\end{array}$ & $\begin{array}{l}U \\
U \\
U \\
U \\
U \\
U \\
U\end{array}$ & $\begin{array}{l}D \\
D \\
D \\
D \\
D \\
D \\
D\end{array}$ & 5 \\
\hline
\end{tabular}

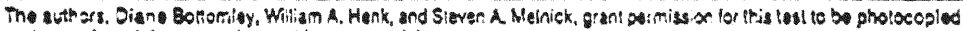
and rosodieac. li may not be ussed lor commoreial outposas. 


\section{APPENDIX B (continued)}

\section{APPENDIX C}

The Writer Self-Perception Scale scoring sheet

Student name

Teacher

Grade Date

Scoring key: $S=$ Strongly Agree (SA)

$4=$ Agree (A)

$3=$ Undecided $(U)$

2 = Disagree (D)

1 = Strongly Disagree (SD)

Scales

\begin{tabular}{|c|c|c|c|c|c|}
\hline $\begin{array}{l}\text { General } \\
\text { Progress (GPR) }\end{array}$ & $\begin{array}{l}\text { Specific } \\
\text { Progress (SPR) }\end{array}$ & $\begin{array}{l}\text { Observational } \\
\text { Comparison } 10\end{array}$ & & $\begin{array}{l}\text { Social } \\
\text { Feedback (SF) }\end{array}$ & $\begin{array}{l}\text { Physiological } \\
\text { States (PS) }\end{array}$ \\
\hline $\begin{array}{l}3 .= \\
6 .= \\
12 .= \\
14 .= \\
17 .= \\
18 .= \\
19 . \square\end{array}$ & $\begin{array}{l}22 . \square \\
25 . \square \\
29 . \square \\
31 . \square \\
34 . \square \\
36 . \square \\
38 . \square\end{array}$ & $\begin{array}{l}1 . \square \\
4 . \square \\
8 . \square \\
11 . \square \\
16 . \square \\
21 . \square \\
23 . \square \\
26 . \square \\
30 . \square\end{array}$ & & $\begin{array}{l}5 . \\
9 . \\
10 . \\
13 . \square \\
28 . \square \\
33 . \square \\
37 . \square\end{array}$ & $\begin{array}{l}2 . \square \\
7 . \square \\
24 . \square \\
32 . \square \\
35 . \square\end{array}$ \\
\hline $\begin{array}{l}\text { Raw score } \\
\quad \text { of } 40\end{array}$ & _ of 35 & $\begin{array}{r}\text { Raw Scores } \\
\text { of } 45\end{array}$ & & _ of 35 & - of 30 \\
\hline $\begin{array}{l}\text { Score } \\
\text { interpretation }\end{array}$ & GPR & SPR & $O C$ & SF & PS \\
\hline $\begin{array}{l}\text { High } \\
\text { Average } \\
\text { Low }\end{array}$ & $\begin{array}{l}39+ \\
35 \\
30\end{array}$ & $\begin{array}{l}34+ \\
29 \\
24\end{array}$ & $\begin{array}{l}37+ \\
30 \\
23\end{array}$ & $\begin{array}{l}32+ \\
27 \\
22\end{array}$ & $\begin{array}{l}28+ \\
22 \\
16\end{array}$ \\
\hline
\end{tabular}


Appendix C - Dade County Public Schools Approval Letter 


\section{DADE COUNTY PUBLIC SCHOOLS}

EOUCATIONAL EVALUA-ICN 3 WAMGEMENT ANALYSIS ISCO BISCAYNE 3OULEVARO. SUITE 225 - MIAMI. FLORIOA 33132

Roger C. Cuevas

suconntindent of scroc,

Rober A. Collins

Exncstive Drector

Equeabonal Evaluation and Waracerent dnaly sis

(205) 89507528

FAX, 928-757

October 15,1997

Oad County Sehool Sasrd o. Solomen C. Stmion, Crur

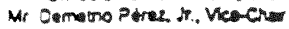

W. G. Hom Braboct Wr. Ronver Dias is Pon Ms. Perta iabares Herten Me. 8etry. H. xhen Or. Hiened Hex Wr3. Mansy Swatis Morse Ms. Frevenca S. Whon

Ms. Artis M. Gray

10364 S.W. 117 Street

Miami, Florida 33176

Dear Ms. Gray:

I am pleased to inform you that the Research Review Committee of the Dade County Public Schools (DCPSI has approved your request to conduct the study, "The Effect of Cross.Age Peer Tutoring on the Writing Skills of Third and Fourth Grad Students Preparing for the Florida Writes Test." The approval is granted with the following conditions:

1. Participation of a school in the study is at the discretion of the principal. A copy of this approval letter must be presented to the principal.

2. The participation of all subjects is voluntary.

3. The anonymity and confidentiality of all subjects must be assured.

4. Parent permission torms must be secured for all participating students prior to the beginning of the stud\%.

5. The study will involve approximately 130 DCPS students in grades 3 and 4 . The assessment portion of the study will not exceed 45 minutas per student.

6. Teacher participation is voluntary.

7. Dis:uption of the schosl's routine by the data callection activities of the study must je kzpt a: a minimum. Gata sollection activities must not interfere with the district's testing schedule.

It should ze emphasized that the approval of the Research Review Committee dces not constitute an andorsement of the study. It is simply a permission is request the roluntary crope:ation in the study of individuals associated with the JCPS. it is your reszonsibility :o ensure that approprate prozedures are sollowed in sequeseing an individual's cooperation. and that all aspacis of the study ara sonducted n a profssional manner. With egard to the at:er. maxa cer:ain tha! all cccuments and instruments distrbuted within the JCPS as a part a the study ara carefuly edited. 


\section{Appendix C (conisinued)}

The revisions to the Spanish varsion of the parent permission form, which are suggestad by the Information Services of the OCPS. will be lowwarded when they are completed. If you have any questions regarding the revisions, please contact me.

The approval numbar for your study is 524 . This number should ba used in all communications to clearly identify the study as approyed by the Research Review Committes. The approval expires on December 31, 1998. Ouring the approval period, the study must adhere to the design, procedures and instruments which were submitted to the Research Review Committes. If there are any changes in the study as it relates to the OCPS, it may be necassary to resubmit your request to the committee. Failure to notify me of such a change may result in the cancallation of the spproyal.

If you have any questions, pleass call mat (305) 995.7501 . Finally, remember to forward an abstract of the study when it is complate. On behalf of the Research Raview Committes. I want to wish you every succass with you? study.

Sincaraly,

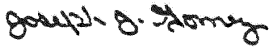

Joseph J. Gomez, Ph.D.

Chairperson

Research Reviow Commitice

JJG:cg 
Appendix D - English Version of the Parental Permission Letter 
Dear Parents,

I am currently working on my doctorate at Elorida International University. I will be conducting a research project this semester. The purpose of the research will be to investigate the effects of cross-age writing response groups on the writing skilis of third and fourth grade students who are being prepared for the Elorida Writes Test.

Last year my fifth grade students worked for two weeks with a fourth grade class to help them prepare for the Florida Writes Test. This project produced some promising and exciting results. Both groups of students became motivated to improve their writing skills. The positive response of all the students involved and the scores on the Florida Writes Test for the fourth grade students in the participating classroom prompted me to select this project as my dissertation study.

Participation in this project will not entail any special treatment or any change in your child's normal classroom routine. The results of a School Made Writing Pretest and posttest, as well as the fourth grade Florida Writes Tests will be analyzed. Individual information (SAT scores and the results of an attitude survey given at the end of the project) will be necessary. Information obtained will be strictly confidential. The student's name wil not appear anywhere in this study. All that is required is your willingness to have your child included in the study. The results will be available to the school and parents at the end of the project.

Your cooperation is appreciated. The more students involved in the project, the more valid the research. I truly believe, based on last year's experience, that all of the students will benefit by being a part of this study.

Sincerely,

Artis Gray

Classroom Teacher

Eor further information contact: Artis Gray 382-0792. Homeroom teacher's name Please check ONE:

I grant permission for

be included in the study. (my son/daughter) to

I do not grant permission for

included in the study.

Parent/Guardian's Printed Name

Date

Parent/Guardian's Signature

Date 
Appendix E - Spanish Version of Parental Permission Letter 
Estimados Padres,

Durante este semestre estare' trabajando en mi Doctorado en la Universidad Internacional de la Florida. El proposito de esta investigation sera" ver como grupos de tercero y cuarto grado mejoran su habilidad en la escritura en preparacion para el examen de Florida writes.

El ano pasado mis alumos de quinto grado trabajaron por dos semanas con estudiantes de cuarto grado preparandolos para el examen de Florida Writes. Ese proyecto produjo resultados muy faborables y prometedores. Ambos grupos de estudiantes estuvieron motivados a mejorar sus habilidades de escritura. Esta respuesta tan positiva de todos los estudiantes envueltos en el estudio tanto como los resultados del examen Florida Writes de cuarto grado de la clase participante me motivo a seleccionar este proyecto como mi tema de tesis.

Participacion en este proyecto no significara' trato especial o cambio en le rutina regular de su hijo(a). Los resultados de examenes de escritura administrados por el colegion asi como los resultados del examen de Florida Writes seran evaluados. Informacion individual como el puntaje en el examen SAT y el resultado de una encuesta al final del proyecto seran necesarios.

Toda la informacion obtenida sera extrictamente confidencial. Elnumbre del estudiante no aparecera en ninguna parte en este estudio. Todo lo que se requiere es el desel de que su hijo(a) participe en este programa. El resultado estara disponible para la escuela y padres el final del proyecto.

Apreciamos su cooperacion. Mientras mas estudiantes participen en el proyecto mayor informacion dara la investigacion. Yo creo positivamente, basada en la experiencis del ano pasado, que todos los estudiantes se beneficiaran al participar en este estudio.

Sinceremente,

Artis Gray

Para mas informacion por favor comuniquese con: Artis Gray 382-0792 Nombre de

maestra:

Por favor marear UNO:

Autorizo a mi hijo(a)

sea incluido en el estudio si No

Firma de padre/madre

Fecha

Escribe nombre de padre/madre

Eecha 
Appendix F - Florida Writes! Pretest Narrative Prompt 


\section{Topic}

School is not the only place where we learn things, and teachers are not the only people we learn things from.

Remember a time when you learned something from a friend.

Tell about the time you learned something from a friend so that your reader knows exactly what happened. 
Appendix G - Elorida Writes! Pretest Expository Prompt 
APPENDIX G

Florida Writes! Pretest Expository Prompt

Topic

Many people think that being one age is better than being any other age.

If you could choose to be any age (including your own age right now), how old would you like to be?

Write to explain to your reader what you think life would be like for you at that age. 
Appendix H - Florida Writes! Holistic Scoring and Rubric Explanation 
Florida Department of Education

Florida Writing Assessment Program (FLORIDA WRITES:)

Score Points in Rubric

The rubric further interprets the four major areas of consideration into levels of achievement. The rubric used to score papers in spring 1995 is shown below

\section{Points}

The writing is focused, purposeful, and reflects insight into the writing situation. The paper conveys a sense of completeness and wholeness with adherence to the main idea, and its organizational pattern provides for a logical progression of ideas. The support is substantial, specific, relevant, concrete, and/or illustrative. The paper demonstrates a commitment to and an involvement with the subject, clarity in presentation of ideas, and may use creative writing strategies appropriate to the purpose of the paper. The writing demonstrates a mature command of language (word choice) with freshness of expression. Sentence structure is varied, and sentences are compiete except when fragments are used purposefully. Few, if any, convention

\section{Points} errors occlir in mechanics, usage, and punctuation.

The writing focuses on the topic, and its organizational pattern provides for a progression of ideas, although some lapses may occur. The paper conveys a sense of completeness or wholeness. The support is ample. The writing demonstrates a mature command of language, including precision in word choice. There is variation in senteoce structure, and, with rare exceptions, sentences are complete except when fragments are used purposefully. The paper 4 Points generally follows the conventions of mechanics, usage, and spelling.

The writing is generally focused on the topic but may include extraneous or loosely related material. An organizational pattern is apparent, although some lapses may occur The paper exhibits some sense of completeness or wholeness. The support, including word choice, is adequate, although development may be uneven. There is litile variation in sentence structure, and most sentences are complete. The paper generally follows the conventions of mechanics,

3 Points usage, and spelling

The writing is generally focused on the topic but may include extraneous or loosely related material. An organizational pattern has been attempted, but the paper may lack a sense of comple:eness or wholeness. Some support is included, but development is erratic Word choice is adequate but may be limited, predictable, or occasionally vague. There is little, if any, variation in sentence structure. Knowledge of the conventions of mechanics and usage is usually 2 Points demonstrated, and commonly used words are usually spelled correcily

\section{Points}

The writing is related to the topic out include extraneous or loosely related material Little evidence of an organizational pattem may be demonstrated, and the paper may lack a sense of completecess or wholeness Development of suppor is inadequare or illogical. Word choice is limited, inappropriate or vague There is little, if any, variation in sentence structure, and gross 
ertors in sentence sincture may occur. Ertors in basic conventions of mechanic 3 and usage may 1 Point ocsur, and cormoniy used words may be misspelled

The writing may only minimally address the topic. The paper is tragmentary or incoherent listing of related ideas or sentences or both. Little, if any, development of support or an organizational pattern or both is apparent Limited or inappropriate word choice may obscure mearing. Gross errors in sentence structure and usage may impede communication. Frequent and blatant ertors may occur in the basic conventions of mechanics and usage, and commonly Unscorable used words may be misspelled.

The paper is unscorable because

- the response is not related to what the prompt requested the student to do.

- the response is simply rewiording of the prompt.

- the response is a copy of a published work.

- the student refused to write.

- the response is illezible.

- the response is incomprehensible (words are arranged in such a way that no meaning is conveyed)

- the response contains an insufficient amount of writing to determine if the student was attempting 10 address the prompt. the ariting folder is blank. 


\section{APRSDOX H (Cortinued) \\ Florida Deparment of Education \\ Florida Writing Assessment Program (FLORIDA FRITES!) \\ Holistic Scoring Method}

Definition of Holistic Scoring

Holistic scoring is a method by which trained readers evaluate a piece of writing for its overall quality. The holistic scoring used in Florida requires readers to evaluase the work as a whole, while considering four elements: focus, organization, suppor, and conventions. This method is somerimes called focused holistic scoring. In this type of scoring, readers are trained not to become overly concerned with any one sspect of writing but to look at a response as whole.

Focus

Focus refers to how clearly the paper presents and maintains 2 main idea, theme, or unifying point Papers representing the higher end of the point scale demonstrate a consistent awareness of the topic and do not contain extraneous information.

Organization

Organization refers to the structure or plan of develogment (beginning, middle, and end) and whether the points logically relate to one another. Organizstion refers to (1) the use of transitional devices to signal the relationship of the supporing ideas to the main idea, theme, or unifying point and (2) the evidence of a connection between sentences. Papers representing the higher end of the point seale use transitions to signal the plan or text structure and end with summary or concluding statements.

Support

Support refers to the quality of the details used to explain, clarify, or define. The quality of suppor depends on word choice, specificity, depth, credibility, and thoroughness. Papers representing the higher end of the point scale provide fully developed examples and illustrations in which the relationship between the supporting ideas and the topic is cleas.

Conventions

Conventions refer to punctuation, capitalization, spelling, and variation in sentence used in the pacer. These conventions are basic writing skills included in Florida's Minimum Student Performance Standerds and the Uniform Student Performance Standerds for Language Arts Pspers cepresenting the higher end of the scale follow, with few exceptions, the conventions of punctuation, capitalization and spelling and use a varety of sentence stuctures to present ideas. 
Appendix I - Daily Writing Prompts 


\title{
APPENDIX I
}

Summary of Writing Activities

\begin{abstract}
week Activity
Prompt

1 Pretest

Expository Prompt

Many people think that being one age is better than being any other age.

If you could choose to be any age (including your own age right now), how old would you like to be?

Write to explain to your reader what you think life would be like for you at that age.

Narrative Prompt

School is not the only place where we learn things, and teachers are not the only people we learn things from.

Remember a time when you learned something from a friend.

Te11 about the time you learned something from a friend so that your reader knows exactly what happened.
\end{abstract}

\footnotetext{
Week Activity

2 "Movies in My Mind"

Introduction and modeling of this technique to the tutors by the teacher. Students practiced this technique, in groups of four with their own writing.
} 
Prompt: Finish this idea: "The best thing that happened to me at school last year was.."

Week Activity

\section{3}

"Pointing"

Procedure:

Teacher introduced and

modeled pointing to the tutors. students practiced in their groups.

Prompt: Describe the way your think a creature from another planet would look.

Week Activity

4

"Summarizing"

Procedure:

Teacher introduced and modeled Summarizing. Students practiced in their groups using their writing.

Prompt: Can you remember the happiest day you ever had? Describe it.

Researcher worked with third grade experimental group in their regular language classxoom to prepare them for the tutoring sessions.

Week Activity Prompt:

5 Experimental Sessions Began

"I don" $t$ believe in ghosts, but..."

Response technique used:

"Movies in My Mind" 
Week $\quad$ Activity
3 Response technique
used:
"Movies in My Mind"

Week Activity

6 Response technique used:

"Movies in My Mind"
Prompt:

Write a letter to

Christopher Columbus.

Tell him some of the things

that are the same today as in

his time, and some of the

things that are different

today.

Prompt:

Your big brother asked you to play on his football team because a player was sick. Tell a story about your experience.

Prompt:

Describe the most frightening monster you can imagine.

Prompt: You are on the Mayflower sailing to a new world. Describe your experiences. 


\section{APPENDIX I (continued)}

Week Activity

10 Response technique used:

"Pointing"

Prompt:

Think of an animal that must prepare for winter. Pretend you are that animal. Write about your activities.

\section{Week Activity}

11 Response technique used: Prompt: Select one of these "pointing" titles and write a story. The Eirst Snowfall, The Missing Present, or The Magic Tree.

Week Activity

12 Response technique used: Prompt:

"Pointing"

Describe the most interesting present you ever received.

\section{Week Activity}

13 Response technique used:

"Summarizing"

Prompt:

You are a reporter. Write a news story about a child who met Santa on Christmas Eve.

Week Activity

Prompt:

14 Response technique

Tell what makes a good friend. used:

"Summarizing" 


\section{APPENDIX I (continued)}

Week Activity

14 Response technique used:

"Summarizing"

Prompt:

Write a winter mystery. Think of a title or use one of these: The Strange Footprints or The Thief in the snowstorm.

Week Activity

16 Postest

Narrative Prompt:

Many people have found things.

Before you begin writing, think about a time when you or someone else found something.

Now tell a story about the time you or someone else found something.

Expository Prompt:

Many people have a favorite place.

Before you begin writing, think about this one place and why it is your favorite place.

Now explain why this place is your favorite. 
Appendix J - Florida Writes! Posttest Narrative Prompt 


\section{APPENDIX J}

Florida Writes! Posttest Narrative Prompt

\section{Topic}

Many people have found things.

Before you begin writing, think about a time when you or someone else found something.

Now tell a story about the time you or someone else found something. 


\section{Appendix K - Elorida Writes! Posttest Expository Prompt}




\section{APPENDIX K}

Elorida Writes! Posttest Expository Writing Prompt

\section{$\underline{\text { Topic }}$}

Most people have a favorite place.

Before you begin writing, think about this one place and why it is your favorite.

Now explain why this place is your favorite. 


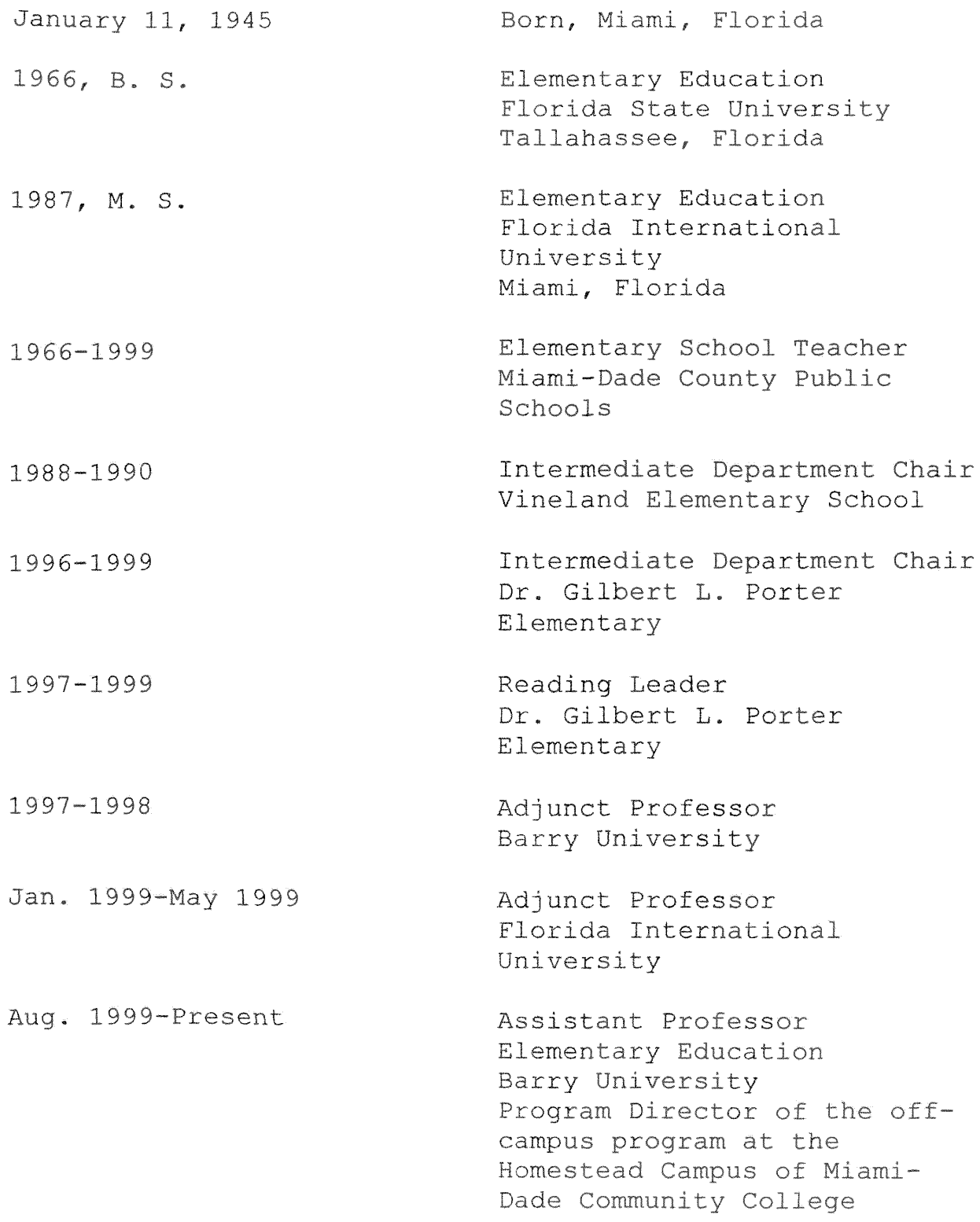

